\title{
22 Associated motion in Tungusic languages: a case of mixed argument structure
}

\author{
Brigitte Pakendorf \& Natalia Stoynova
}

\begin{abstract}
The languages of South America and Australia are known for their morphologically and semantically elaborate systems of Associated Motion (AM). In contrast, the five Tungusic languages discussed here, which belong to the Northern and the Southern branch of the family, have only a single suffix pertaining to this category. This morpheme expresses a motion event that precedes the verb event. It is deictically neutral, i.e. can refer to both translocative and cislocative motion, although translocative readings predominate.

The cross-linguistically most striking feature of AM in the Tungusic languages is the fact that not only base verb arguments can be expressed, but so can arguments typical of motion verbs, called 'spatial arguments' in the paper. We explore the argument structure of verbs marked with the AM-suffix in detail and find that both formal considerations (a preference for only one overt argument) and pragmatic considerations (the choice to foreground the spatial argument over the verb argument) play a role in which argument(s) get expressed.
\end{abstract}

\section{Keywords}

Siberia, Russian Far East, corpus data, independent construction, echo construction, converb construction, foregrounding, base verb argument, spatial argument

\section{Introduction}

The grammatical category of Associated Motion (AM) has been described in some detail for the languages of Australia and South America (e.g. Koch 1984; Wilkins 1991; Rose 2015; Guillaume 2016), while the related category of Motion-cum-Purpose has been described mainly in Mesoamerican languages (e.g. Haviland 1993; Zavala Maldonado 2000). These domains of verbal morphology have only recently been investigated in the languages of Northern Asia in general (Volkov and Stenin 2019) and the Tungusic family in particular (Stoynova 2016, 2017; Alonso de la Fuente and Jacques 2018). This paucity of previous descriptions of Associated Motion (including Motion-cum-Purpose) in the languages of Northern Asia can probably be partly explained by the fact that this is a rare morphological category in the languages of Eurasia overall, as can be seen from the survey conducted by Ross (this volume).

All the Tungusic languages, including the now-extinct Classical Manchu, have a productive suffix with the meaning of 'to go and V' or 'to go in order to V' (1). We will here refer to it as the $n d A$-suffix, following the reconstruction proposed in Benzing (1955: 120). In this article, we focus on the argument structure of verbs with the $n d A$ suffix in several Tungusic languages, based on frequency counts of various constructions in narrative corpora (for other studies that make use of frequency counts in narrative corpora see Payne, this volume, and Tallmann, this volume). The languages we discuss, namely Nanai, Ulch, Udihe, Even, and Negidal, belong to two major branches of the Tungusic family, Southern and Northern Tungusic (see Figure 1 for an

Brigitte Pakendorf, Dynamique du Langage, UMR5596, CNRS \& Université de Lyon, brigitte.pakendorf@cnrs.fr

Natalia Stoynova, Russian Language Institute RAS \& National Research University

Higher School of Economics, stoynova @yandex.ru 
attempt at a consensus tree of the Tungusic languages; for more information see Section 2).

(1) Udihe (Nikolaeva et al. 2002: 144, txt 17, 3)

emende ise-ne-je ni em'e

witch see-AM-IMP who come

'Witch, go and see who's come.'

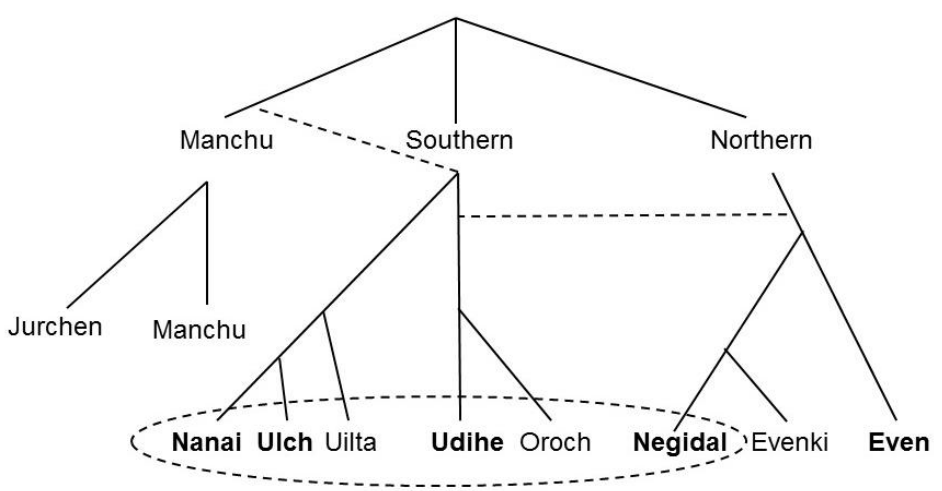

Figure 1: Attempt at a consensus tree of Tungusic genealogical relationships. The tree shown with solid branches is based on Atknine (1997: 111), while the dotted branches indicate the proposals of Comrie (1981: 58 - the Manchu branch together with the Southern branch — and Janhunen (2012: 16): Udihe/Oroch together with the Northern Tungusic languages, and the Manchu branch together with Nanai/Ulch/Uilta. The languages that the article is based on are indicated in bold font, and the dotted circle unites the languages spoken in the Lower Amur region.

A notable feature of verbs carrying the $n d A$-suffix is their mixed argument structure. They can both inherit the arguments of the base verb and take arguments that are typical of motion verbs (Goal, Source, Trajectory). For instance, in (2) the accusative argument 'girl' is inherited from the base verb 'take', while the allative argument 'to her father' is licensed by the $n d A$-suffix. Note that there is no overt motion verb in the sentence that could license the Goal argument.

$$
\begin{aligned}
& \text { Bystraja Even (NIG_legend_Alngej_062) }{ }^{1} \\
& \text { nan ga-sči-na-ri-n akan-taki-n asatkam } \\
& \text { and take-CONAT-AM-PST-3SG father-ALL-POSS.3SG girl.ACC } \\
& \text { 'And he went to her father to ask for (lit. take) the girl (in marriage).' }
\end{aligned}
$$

Few studies of AM-markers in languages of the world have explicitly addressed the argument structure of AM-verbs, but where it is mentioned it is nearly always the base verb argument that is expressed, not the argument of the motion verb. Thus, Wilkins (1991: 211) writes that in Mparntwe Arrernte "...a verb form inflected for AM takes exactly the same case frame(s) and adjunct possibilities as the verb stem without any AM inflection. Moreover, the use of associated motion inflections does not appear to license, nor increase the likelihood of, the occurrence of those spatial adjuncts that typically cooccur with motion verbs (such as ablative and allative phrases)" (see also Zavala

\footnotetext{
${ }^{1}$ Examples from our own text collections are provided with short source labels following the conventions used in the respective corpora (usually the speaker code, the title of the text, and the number of the sentence). For examples taken from published sources, we indicate the page, text and sentence number. See Section 2 and the Appendix for information on the text collections used in the study. Elicited examples are marked as such, with the speaker code added.
} 
Maldonado [2000: 143] on Olutec and O'Connor [2007: 111-112] on Lowland Chontal). Indeed, Rose (2015: 122) argues that in languages where the associated motion marker is identical to a motion verb, a grammatical category of AM can be posited only when the argument structure of the clause is provided solely by the base verb. The Pama-Nyungan languages Warlpiri and Kaytetye constitute a marked exception, since here the element expressing the motion event can add a Goal or Source argument (Simpson 2001: 180; Koch, this volume). However, while in Kaytetye a bound AM-marker appears to occasionally license a Goal or Source argument (Koch, this volume: examples [40b] and [41]), in Warlpiri a Goal argument can only be added if in participle-verb compounds it is the finite element of the compound that expresses the motion. This is quite different from what we find in the Tungusic languages studied here, where it is a bound morpheme that can add a spatial argument. The Tungusic AM constructions discussed here thus appear to be cross-linguistically quite rare and will add to our understanding of AM as a grammatical category.

The following terms are used in the paper. The suffix $-n d A$ is here called the associated motion suffix (abbreviated as AM-suffix or $n d A$-suffix), following Guillaume's (2016: 92) definition: "An AM marker is a grammatical morpheme that is associated with the verb and that has among its possible functions the coding of translational motion". See Section 3.2 for some remarks on its semantics in the Tungusic languages. Verbs marked with this suffix are referred to as $n d A$-verbs. The two events that are introduced by a $n d A$-verb are called in the paper the "motion event" and the "base verb event" or simply the "verb event". The arguments of the $n d A$-verb are divided into "base verb arguments" or simply "verb arguments" (i.e. arguments that are inherited from the base verb, often direct objects) and "spatial arguments" (i.e. arguments or adjuncts that are typical of motion verbs, most notably Goal arguments).

The $n d A$-suffix is attested in the languages under consideration in three types of constructions with one and the same meaning. Firstly, it can mark the single independent verb (i.e. a finite verb in main clauses or a non-finite verb in subordinate clauses), as illustrated in (1) and (2) above and (4) below, a construction that we label "independent" here. Secondly, it can mark the converb in biverbal constructions consisting of a simultaneous converb plus finite motion verb (3a); these are called "converbial constructions/uses" here. Lastly, as shown in (3b), it can mark a finite base verb that follows (or very rarely precedes) a finite verb of motion, a type of use that we here label "echo construction" following Guillaume (2006: 424). Since both the converbial and the echo constructions contain a seemingly redundant verb of motion in addition to the $n d A$ verb, we subsume them under the cover term "pleonastic constructions/uses".

a. Lamunkhin Even (AXK_svatovstvo_006)



'While they were living in their camp like this, other Evens, having come from afar, came to talk with them.'

\footnotetext{
${ }^{2}$ Note that we choose this term over the more iconic term "motion argument" in order to avoid confusion with the notion of 'argument of motion' or 'moving argument', which is used with reference to the argument of the base verb (S, A or O) that is moving when the AM-marker is attached; cf. Guillaume (2016: 113116). From the point of view of the moving argument parameter, the $n d A$-suffix belongs to subject AMmarkers: it expresses consistently the movement of the A or S argument, but not the movement of the Oargument.
} 
b. Udihe (Nikolaeva et al. 2002: 50, txt 10, 19)

zeu-クi-na-mie

zawa-mie

yene-li-e-ni

food-ALN-DEST-PREFL

take-COND.CVB

go-INCEP-PST-3SG

ge:-ne-gi-li-e-ni

bring-AM-REP-INCEP-PST-3SG

'(She) took some food with her and set out to bring her granddaughter back.'

As we show in this paper, both spatial arguments and verb arguments can be expressed with $n d A$-verbs (Section 4.1). However, there are differences in the occurrence of spatial arguments across syntactic constructions: they are expressed more frequently with intransitive $n d A$-verbs and in pleonastic constructions than in independent constructions with transitive $n d A$-verbs. Furthermore, from a cursory analysis it would appear that in pleonastic constructions with an overtly expressed spatial argument this is more often governed by the motion verb than the AM-marked lexical verb (Section 4.2). In those cases where both the verb event and the motion event share an argument (e.g. when the Goal of the motion event is the Location where the verb event takes place) it is the Goal that is more frequently expressed overtly. Nevertheless, some interesting variation occurs, indicating that pragmatic considerations about which event to foreground might play a role in argument expression (Section 4.3).

The paper has the following structure. In Section 2, we give some background information on the languages under discussion as well as on the methodology and the data used in the study. Section 3 contains an overview of formal (3.1) and semantic (3.2) features of AM-constructions in Tungusic languages, while Section 4 deals with the main topic of the paper, namely the argument structure of $n d A$-verbs. In Section 5, we discuss some differences in AM-constructions attested across the Tungusic languages included in the study. Finally, in Section 6 we discuss the empirical data on AM-constructions in the Tungusic languages in a wider cross-linguistic perspective.

\section{Languages included in the study and data used}

Tungusic languages are spoken in Siberia, the Russian Far East, and Northern China (Figure 2). The family includes Evenki, Solon, Even, Negidal, Nanai, Kilen, Uilta (aka Orok), Udihe, Ulch, Oroch, and Manchu. For some of these lects it is questionable whether they are languages (each with several dialects) or rather small language groups. While the classification of the Tungusic languages into one family is uncontroversial, no consensus has yet been achieved on its internal branching. Whereas all classifications agree about the close relationship of Nanai, Ulch, and Uilta on the one hand and Even, Evenki, and Negidal on the other (e.g. Sunik 1968; Atknine 1997; Janhunen 2012; cf. Figure 1), it is uncertain whether Udihe and Oroch cluster with Nanai and Ulch as part of the Southern Tungusic languages (as envisioned by Sunik 1968 and Atknine 1997, among others) or whether they are more closely related to Even, Evenki, and Negidal and thus form part of the Northern Tungusic languages (as suggested by Janhunen 2012). A further branch of the Tungusic family is represented by the extinct language Jurchen as well as Manchu and the closely related Sibe. 


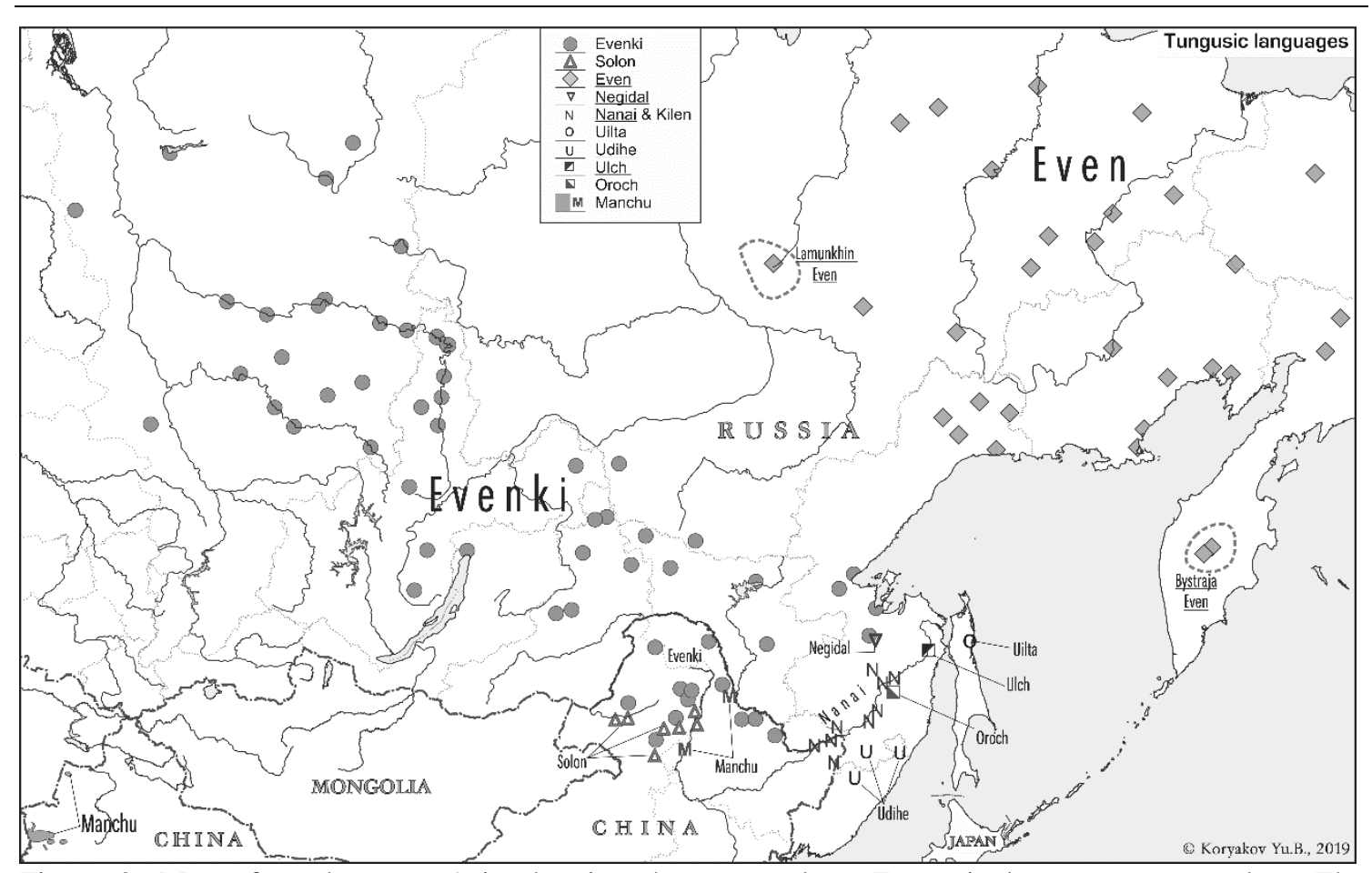

Figure 2: Map of northeastern Asia showing the areas where Tungusic languages are spoken. The underlined names in the legend refer to the five languages which we discuss in detail in the paper.

In this paper, we discuss data from five Tungusic languages of different genealogical subgroups. These are Nanai, Ulch, Udihe, Even, and Negidal, all of which are spoken in the Far East of Russia and in northeastern Siberia.

1) Nanai is spoken in Khabarovsk Krai (and to a lesser extent in Primorsky Krai and on Sakhalin). The language is endangered, with at most 1347 speakers (Census 2010), $11 \%$ of the ethnic group. See Kalinina and Oskolskaya (2016) on the current sociolinguistic situation. It is quite well described (Avrorin 1959, 1961, 1981). There are different dialects of Nanai. The data used in the paper come from the Middle Amur dialect (mostly from the village of Naikhin).

2) Ulch (Ulcha) is spoken in the Ulchsky district of Khabarovsk Krai. It is severely endangered, with only 154 speakers recorded in the 2010 census (Census 2010), 6\% of the ethnic group (cf. Gerasimova 2002; Sumbatova and Gusev 2016). It is underdescribed: only two short grammatical sketches exist to date (Petrova 1936; Sunik 1985).

3) Udihe is spoken in Primorsky Krai by at most 103 individuals (Census 2010), $5.5 \%$ of the ethnic group. The language is severely endangered. It is quite well described (Nikolaeva and Tolskaya 2001).

4) Even is spoken by small and widely dispersed speech communities in northeastern Siberia, from the Lena river in the west to Chukotka, Kamchatka, and the coast of the Okhotsk Sea in the east. It is dialectally highly fragmented (Burykin 2004), and at most 4,900 Evens (22\% of the total ethnic group) still speak the language (Census 2010). These largely belong to the older generation, and the language overall is severely endangered. However, there are big differences in language maintenance among different dialect communities (Pakendorf and Kuz'mina 2016: 587). The data in this study come from two of the geographically and linguistically most differentiated dialects (indicated by dotted circles in Figure 2): the Lamunkhin dialect spoken in central Yakutia and the Bystraja dialect spoken in central Kamchatka. Neither of these dialects has been described in any detail.

5) Negidal used to comprise two dialects, Upper Negidal (Verxovskoj) and Lower Negidal (Nizovskoj). However, the Lower dialect is by now extinct, and Upper Negidal 
is spoken with varying degrees of proficiency by only five ${ }^{3}$ elderly women in the village Vladimirovka and the nearby district centre Polina Osipenko in Khabarovsk Krai (Pakendorf and Aralova 2018). Only very brief grammar sketches exist (Cincius 1982; Kolesnikova and Konstantinova 1968; Khasanova and Pevnov 2003).

The current article is based mostly on textual data (see the Appendix for detailed information on the text collections):

1) The sample of $n d A$-uses in Nanai was extracted from Avrorin (1986), Bel'dy and Bulgakova (2012), and from our own collection of field recordings. Since some variation is attested across different dialects of Nanai, only Middle Amur texts (mostly of the Naikhin variety) were included in the sample.

2) The sample of $n d A$-uses in Ulch was extracted from the archive of L. I. Sem and from our own collection of field recordings. When data from these separate sources were combined, we refer simply to "Ulch".

3) The sample of $n d A$-uses in Udihe was extracted from Nikolaeva et al. (2002, 2003), which are based on the Bikin dialect.

4) The data on Even come from corpora of transcribed, translated and glossed field recordings totalling c. 52,000 words for the Lamunkhin dialect and c. 34,000 words for the Bystraja dialect. The data from the two Even dialects were kept separate given their extreme linguistic differentiation.

5) The Negidal data were taken from a corpus of transcribed, translated, and glossed audio recordings of the Upper dialect comprising c. 47,000 words at time of writing (Pakendorf and Aralova 2017).

There is no unified analysis of the $n d A$-suffix in the literature on Tungusic languages, with some authors including it among the aspectual markers (e.g. Cincius 1982 on Negidal), others among the modal markers (e.g. Malchukov 1995 on Even), and yet others describing them among general verbal derivational suffixes (e.g. Avrorin 1961 on Nanai or Novikova 1980 on Even). ${ }^{4}$ In the text collections we used for the study, the marker is glossed in the following way: PURP (purposive) for Nanai, MPURP (motion with purpose) for Ulch, DIR (directive) for Udihe, INTENT (intentional) for Even, and AM (associated motion) for Negidal. Note that we adapted the glosses for all languages to provide consistency throughout the paper, and that we do not mark epenthetic vowels separately.

\section{The ndA-suffix: Formal aspects and semantics}

\subsection{Form, frequency, and syntax of the $n d A$-suffix}

In this section, we briefly describe the main morphosyntactic features of the associated motion suffix and discuss its frequency in different Tungusic languages and in

\footnotetext{
${ }^{3}$ Pakendorf \& Aralova (2018) list seven speakers, but speaker 1 and speaker 5 (in their Table 1) have since passed away.

${ }^{4}$ Some terms occurring in different grammatical descriptions of the languages included in this paper are: "purposive derivation" ("poroda celi”; Nanai, Avrorin 1961: 59); "complex verb base with such general meanings as "depart to perform the action expressed by the primary base"” ("složnye glagol'nye osnovy s takimi, naprimer, obščimi značenijami, kak 'otpravit'sja soveršit' dejstvie oboznačennoe pervoobraznoj osnovoj"” (Ulch, Sunik 1985: 50); "directive” (Udihe, Nikolaeva, Tolskaya 2001: 232-233); “directionalintentional" (Even, Malchukov 1995: 15); "secondary verb base expressing motion or departure of the agent with the goal of performing an action" ("vtoroobraznye glagol'nye osnovy, oboznačajuščie dviženie, otpravlenie dejstvujuščego lica s cel'ju soveršit' to ili inoe dejstvie"; Even, Novikova 1980: 37); and "aspect of departure to perform an action" ("vid otpravlenija dlja soveršenija dejstvija"; Negidal, Cincius 1982: 23).
} 
different types of constructions. The argument structure of $n d A$-verbs and especially the encoding of spatial arguments will be discussed in detail in Section 4.

With the exception of Classical Manchu, the Tungusic languages have only one associated motion suffix. ${ }^{5}$ This has the following form in the languages under discussion: $-n d A$ (with the allomorph -ni [Naikhin] -nindA [Gorin]) or - $n A$ in different dialects of Nanai (cf. Avrorin 1961: 61-62), $-\eta d A$ in Ulch (cf. Sunik 1985: 50), $-n A$ in Udihe (Nikolaeva and Tolskaya 2001: 232-233), $-n A$ in Even and $-n A$ : in Negidal. In these languages the suffix expresses prior motion by the subject/agent. It is deictically neutral, i.e. depending on the context it has an itive ('go') or ventive ('come') reading (see Section 3.2 for more detail). Classical Manchu, in contrast, has both an itive suffix $-n A$ and a distinct ventive suffix -ndzi (Alonso de la Fuente and Jacques 2018: 505). While the $n d A$-suffix in the Tungusic languages (including the Classical Manchu itive) is most probably at least partially cognate and can thus be assumed to go back to Proto-Tungusic, the precise etymology of the variants in the different languages remains opaque (see Alonso de la Fuente \& Jacques 2018: 519-520 for discussion).

The $n d A$-suffix belongs to the derivational suffixes in Tungusic. The verb stem marked by this suffix is compatible with the whole set of mood, tense, and person-number inflections. Within the stem, the $n d A$-suffix can be followed by some other derivational suffixes, e.g. the causative and desiderative (see Stoynova [2016: 25-31] for more detail on possible combinations attested in Nanai).

Table 1 contains comparative data on the frequency of -ndA in the languages under discussion. Note that we excluded clearly lexicalized cases, such as tu:ndo- 'to fall down, crash down' in Nanai, which can be analysed as tu:-ndo- 'fall-AM', as well as incomplete utterances (that consisted of only a converb carrying the $n d A$-suffix) and examples in which the suffix didn't add any motion event to the verb, but appeared rather to have aspectual readings. The latter are relatively frequent in the Udihe texts and appear to express perfective meanings, with the specific reading depending on the aspectual features of the verb stem, e.g. inceptive in (4a) and completive in (4b). Such aspectual extensions of AM markers are also reported for Kiranti languages (Jacques et al., this volume), the Pano language Chácobo, where subsequent motion AM markers indicate completive semantics of the main event (Tallmann, this volume), and Nilotic directionals, where the itive indicates imperfectivity and the ventive tends to indicate inchoativity and perfectiveness (Payne, this volume).

(4) a. Udihe (Nikolaeva et al. 2003: 17; txt 1,7)

$\begin{array}{llllll}\text { tukca } & \text { awa-za } & \text { muda-tigi-ni } & \text { tukä-yi-si:-ni } & \text { nautu } & \text { bi:-ni } \\ \text { hare } & \text { this-SIDE } & \text { end-LAT-SG } & \text { run-AM-ANT-3SG } & \text { raccoon } & \text { be-3SG }\end{array}$

'The hare began to run to the other end, (but) the raccoon dog was already there (as well).'

b. Udihe (Nikolaeva et al. 2002: 180; txt 24, 13)

diga-mi mute:-si činda gabzi-ne-gi-e-ni...

eat-SIM.CVB finish-ANT.CVB bird cheer-AM-REP-PST-3SG

'Having finished eating, the bird cheered up...'

\section{Table 1. The frequency of $-n d A$}

\footnotetext{
${ }^{5}$ Note, however, that a second suffix with the meaning of 'go and V and return' is grammaticalizing out of the combination of the associated motion suffix and an erstwhile imperfective suffix, as we discuss in Section 3.2. In Bystraja Even and Negidal, this grammaticalization process appears to be completed, so that one could speak of two associated motion suffixes in these lects from a synchronic perspective.
} 


\begin{tabular}{|l|r|r|r|}
\hline Language & N of uses & N of sentences & N uses / 1000 sentences \\
\hline Nanai & 138 & 6356 & 22 \\
\hline Ulch & 98 & 7477 & 13 \\
\hline Udihe & 188 & 3313 & 57 \\
\hline Lamunkhin Even & 100 & 8641 & 12 \\
\hline Bystraja Even & 166 & 7140 & 23 \\
\hline Negidal & 156 & 8554 & 18 \\
\hline
\end{tabular}

There are notable differences in frequency of use of the $n d A$-suffix: Udihe exhibits a nearly three- to fivefold higher frequency of use of the AM-suffix than its sisters, and there are big differences even between the closely related languages Nanai and Ulch or the two Even dialects. Given that the Even dialectal corpora are quite similar in genre composition, as are the different sources for the Southern Tungusic languages (see Appendix), these discrepancies are likely to reflect actual linguistic divergence rather than merely being due to differences in the make-up of the corpora. However, it should be kept in mind that the corpora are rather small, so that the observed differences might simply be due to chance.

Overall, the frequency of the AM-suffix in the Tungusic languages is quite low: all except Udihe have a lower frequency than that observed by Rose (2015: 148) in Mojeño Trinitario - a language which she qualifies as making "infrequent" use of associated motion in comparison with other languages, especially with Arrernte, where in some texts more than $30 \%$ of the verbs carry an AM-marker. ${ }^{6}$ Similarly, for the PamaNyungan language Kaytetye Koch (this volume) counts "some 240 AM forms" in 2870 sentences, i.e. 84 uses/1000 sentences. The AM-suffix is also infrequent in comparison to other derivational suffixes attested in the same languages. For instance, the token frequency of the most frequent verbal derivational suffix in Nanai, the repetitive - $g O$, is $260 / 1000$ sentences, ten times higher than that of $-n d A$.

As mentioned in the introduction, the suffix is used in three types of syntactic constructions: independent, pleonastic converbial, and pleonastic echo. Examples (1) and (2) above and (5) below illustrate the independent use of the suffix, in which it is attached to the single finite verb, e.g. 'search' in (5). Examples (3a and 6a) illustrate its pleonastic converbial use, which consists of a finite motion verb and a lexical verb marked with $n d A$ in a non-finite converbial form (the simultaneous converb -mi). The same meaning can be expressed by a combination of the finite motion verb and the plain simultaneous converb, without the AM-marker, cf. (6b). Such examples are, however, quite rare in Nanai and Ulch, and practically absent in Even and Negidal. In the Bystraja dialect of Even only two examples of the converbial construction are found; these carry the purposive converb instead of the simultaneous converb -mi (6c). Nanai speakers also accept such constructions with the purposive converb; however no examples occur in the narrative corpus. The echo construction, which consists of a finite verb of motion and a finite $n d A$-verb, is exemplified in ( $3 b$ ) above and (7). In Udihe, one example was found in which the $n d A$-verb is finite and the motion verb carries the converb suffix (8).

Ulch (Sunik 1985: 74, txt 3, 155)

\footnotetext{
${ }^{6}$ Rose mentions 62 occurrences of the two most frequent AM-markers in nearly 2000 sentences, i.e. a frequency of use of c. 31/1000 sentences.
} 
ịlan-žị bagdi-ču gịvu gala-ydo-xan

three-INS leg-COM roe search-AM-PST

'He went to search for a roe with three legs.'

a. Nanai (fna_110820_so_Skazka.023)
sogdata-wa
wa:-nda-mi
onว- $x \partial-\check{c} i$
fish-ACC
kill-AM-SIM.CVB.SG
go-PST-3PL

'They went to fish (lit. they went while going to kill fish).'

b. Ulch (lpd_20180720_nst_SluchajMuzhUpalVProrubj)

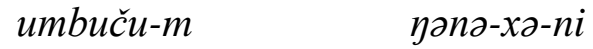

fish-SIM.CVB.SG go-PST-3SG

'He went fishing'

c. Bystraja Even (SPA_life_006)

$\begin{array}{lllll}\text { ńan } & \text { ta-duk } & \text { noka } & \text { tor-teki-n } & \text { or-ri-wu } \\ \text { and DIST-ABL } & \text { Sakha } & \text { earth-ALL-POSS.3SG } & \text { go-PST-1SG } \\ \text { upkuči-d-ne-de-ji } & & \text { korowa } & \text { doktor-du-n } \\ \text { learn-PROG-AM-PURP-PREFL.SG } & \text { cow.R } & \text { doctor.R-DAT-POSS.3SG }\end{array}$

'And from there I went to Yakutia to study veterinary medicine (lit. cow doctor).'

(7) Negidal (Pakendorf and Aralova 2017, DIN_savkan: 77)

$\begin{array}{lll}\text { saßkan } & \text { omo-kal } & \text { jep-na-kal } \\ \text { pers.name } & \text { come-IMP.SG } & \text { eat-AM-IMP.SG }\end{array}$

'Savkan, come to eat/come and eat.'

(8) Udihe (Nikolaeva et al. 2002: 81, txt 13, 143)
uta-digi
eme-gi-m(i)
(g)une:-n(i)
DIST-ABL
come-REP-SIM.CVB
sine-we
mamasa-na-mi
say.PST-3SG
you-ACC
wife-DEST-PREFL
eme-mi
ge:-ne-zeye-i
'After returning from there, he said: "I will come and marry you".'

The independent use is more frequent than the pleonastic ones in all the lects examined, with the exception of the Lamunkhin dialect of Even (Table 2): here, the pleonastic constructions are as frequent as the independent ones. Furthermore, the frequency of the converbial vs. echo subtype of the pleonastic construction differs among the languages. In Nanai, Ulch, and Lamunkhin Even, the main subtype is converbial, and echo constructions are very rare. In contrast, in Bystraja Even the main subtype is the echo construction, with hardly any converbial constructions occurring. In Udihe and Negidal the converbial and echo constructions occur with comparable frequency. These patterns of frequency do not correlate with genealogical or areal groupings (cf. Figures 1 and 2).

Table 2. Frequency of the different types of constructions

\begin{tabular}{|l|l|l|c|c|}
\hline Language & Independent & Pleonastic & $\begin{array}{c}\text { Proportion of } \\
\text { pleonastic uses } \\
\text { (over all } \\
\text { constructions) }\end{array}$ & $\begin{array}{c}\text { Proportion of } \\
\text { echo uses (over } \\
\text { pleonastic } \\
\text { constructions) }\end{array}$ \\
\hline
\end{tabular}




\begin{tabular}{|c|c|c|c|c|c|}
\hline & & converbial & echo & I & \\
\hline Nanai & 96 & 40 & 2 & $30 \%$ & $5 \%$ \\
\hline Ulch & 68 & 27 & 3 & $31 \%$ & $10 \%$ \\
\hline Udihe & 135 & 25 & 28 & $28 \%$ & $53 \%$ \\
\hline Lamunkhin Even & 50 & 47 & 3 & $50 \%$ & $6 \%$ \\
\hline Bystraja Even & 138 & 2 & 26 & $17 \%$ & $93 \%$ \\
\hline Negidal & 114 & 18 & 24 & $27 \%$ & $57 \%$ \\
\hline
\end{tabular}

\subsection{The semantics of $-n d A$}

The AM-suffix can take different directional interpretations in the independent construction. ${ }^{7}$ In particular, both the 'go'-reading (as in [1], [2], and [5] above) and the 'come'-reading (9a) are available, although the first one is more typical: only $9 \%$ of Udihe and $27 \%$ of Nanai examples carry this reading (Stoynova 2018); in the Northern Tungusic lects only c. $16 \%$ of the examples are ventive. Thus, the AM-suffix appears to be deictically neutral, with the specific interpretation furnished either by the context or by additional deictic elements in the sentence. Such deictically neutral AM markers are cross-linguistically quite rare, being found in only $18 \%$ of a worldwide sample (Ross, this volume; see Dryer [this volume] for an example from an Algonquian language). For instance, (9a) is part of a conversation between two sisters that takes place in the older sister's house, and the context makes it clear that the older sister, who is speaking and thus represents the deictic centre, assumes that her younger sister, who lives far away, will come and visit her frequently. In contrast, if the implicit goal of motion of this utterance were a third person, then the reading would be one of translocative motion ("you will probably go to see him/her frequently'). In (9b), the allative-marked proximal demonstrative eweski clearly signals the cislocative motion (see the similar example [19b] below), while in (9c) it is the 1SG pronoun that signals that the motion carried by the AMsuffix on 'help' is cislocative (see also [17a] with an overt 2SG addressee).

a. Negidal (Pakendorf and Aralova 2017, APN_two_sisters: 55)

itce - na: - si $-k t \partial-n a-$ sun $=\jmath \partial k \partial$

see-AM-IPFV-MULT-POT-2PL=PRES

'You will probably come to see (me) frequently.'

b. Bystraja Even (RME_Uindja_041)

Uindza ia-sči-d-na-ri-s

pers.name do.what-CONAT-PROG-AM-PST-2SG

'Uindja, what did you come here to do?'

ewe-ski

PROX-ADV.ALL

c. Negidal (Pakendorf and Aralova 2017, DIN_Emeksikan: 35)

$\begin{array}{llll}\text { oj } & \boldsymbol{m i n}-\boldsymbol{d} \boldsymbol{u}=d a & & \text { osa } \quad o:-d a-k i-n \\ \text { PROX } & \text { 1SG-DAT=PTL } & & \text { bad become-NFUT-COND-3SG } \\ n i=d a & & \text { o-ta-tin } & \text { bəla-na:-ja } \\ \text { who=PTL } & \text { NEG-FUT-3PL } & \text { help-AM-NEG.CVB }\end{array}$

\footnotetext{
${ }^{7}$ However, as mentioned in the introduction, two separate markers with different spatial meanings are attested in Manchu (cf. Avrorin 2000: 173-175; Alonso de la Fuente and Jacques 2018): - $n A$ (the cognate of the suffix under discussion) for 'go to V' and -nži for 'come to V'.
} 
'And when it will be bad for me, no-one will come help (me).'

Within both subtypes of pleonastic constructions, the $n d A$-verb can be combined with different motion verbs: not only 'to go' (3b, 6a) and 'to come' (3a, 7), but also verbs which describe a specific manner or trajectory of motion, such as 'run', 'ascend' (10a), 'exit', as well as derived causatives such as emu- 'bring' (< em- 'come') and horu- 'take along' (< hor- 'go'; 10b). This picture differs radically from that of the rich associated motion systems frequently found in languages of Australia and South America. In such systems cumulative expression of AM-meanings and differentiated spatial meanings is attested (i.e. different markers for ' $g o$ and V' and 'come and V', etc.); cf. the overview in Guillaume (2016) and Koch (this volume).

$$
\begin{aligned}
& \text { a. Bystraja Even (PMB_pear_story21) }
\end{aligned}
$$

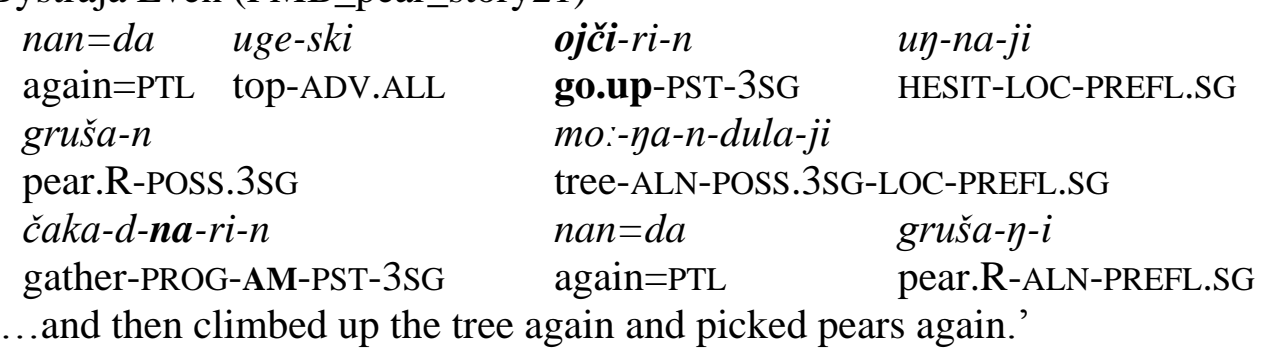

b. Lamunkhin Even (IVK_memories_122)

kosči-ne-mi

herd.reindeer(day)-AM-SIM.CVB

iawči-na-mi=da

herd.reindeer(night)-AM-SIM.CVB $=\mathrm{PTL}$

'... (he) took us along to the day reindeer herding and to the night reindeer herding.'

The combination of the suffixes $-n d A$ and $-s V$ (probably derived from an imperfective marker) has the meaning 'go and V and then return' (11a-b). This is also found in the example (9a) above, where the speaker implies that her sister will come repeatedly to see her, returning to her own home in between every visit. In the text data from the Naikhin dialect of Nanai and Ulch this combination is attested only in habitual contexts (11c, and see also 18d below), even though in elicitation readings with a single event are obtained. This construction is lacking in the Lamunkhin Even and Udihe data and is infrequent in Nanai.

a. Bystraja Even (TEB_childhood_043)

$\begin{array}{lll}a \quad b i \quad \text { uže } & \text { upkut-ne-sči-dzi } \\ \text { but.R } 1 \mathrm{SG} \text { already.R } & \text { learn-AM-IPFV-ANT.CVB } \\ \text { gurge:wči-l-li-wu} & \text { e-du } \\ \text { work-INCEP-PST-1SG } & \text { PROX-DAT }\end{array}$

'But I worked here, having gone to study (i.e. having gone to study and returned).'

b. Negidal (Pakendorf \& Aralova 2017, GIK_2tatarskoe: 54)
səktə $\beta-\beta \partial-\beta u n$
a:-sin- $d a-\beta a j$
neko-ja:n
make.bed-NFUT-1PL.EXCL
sleep-TAM1-PURP-PREFL.PL do-ANT.CVB
itce-na:-si-ja-ßun
yənu-t6a-l $(=g u) \quad$ o-t6a- $l=g u$
see-AM-IPFV-NFUT-1PL.EXCL leave-PST-PL(=Q) NEG-PST-PL=Q
taj

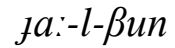


DIST

relative-PL-1PL.EXCL

'We made up our beds; before going to sleep, we went to look whether our relatives had left.'

\section{c. Ulch (spk_170802_so_roditeli) \\ manə sugdata wa:-yda-su-j \\ self fish kill-AM-IPFV-PRS \\ 'She herself goes fishing.'}

The combination $-n d A-s V$ is on its way to being grammaticalized into a dedicated 'go and V and return' marker, with different stages of this process attested in the languages discussed here. In Negidal and Bystraja Even it is more grammaticalized than in Nanai and Ulch, as can be seen from the fact that in Nanai and Ulch the suffix $-s V$ occurs on its own (with a multiplicative/distributive/habitual meaning), whereas in Negidal and Bystraja Even the suffix $-s i$ is attested only in combination with -ndA. Thus for these two languages -ndAsi can be analyzed synchronically as an additional AMmarker distinct from $-n d A$. However, we here gloss $-n d A$ and $-s V$ as two separate suffixes for all four languages where the combination is attested, in order to retain a uniform analysis.

The grammaticalization process presumably started from habitual contexts such as that illustrated in (11c), which are appropriate for the initial meaning of $-s V$ on its own. The next step is a reinterpretation of $-n d A-s V$ as 'go and return' (since going somewhere repeatedly to perform an action implies a return in between each going event). From this follows the extension to uses with reference to a single event, as illustrated in (11a) and (11b). Note that in (9a) above from Negidal the erstwhile imperfective suffix co-occurs with a multiplicative suffix that expresses iterativity of the action. This shows clearly that the habitual meaning still inherent in the imperfective suffix in Nanai and Ulch has been completely bleached in Negidal (and possibly in Even as well).

The meaning 'go and V and return' (called 'roundtrip' by Ross [this volume] and Dryer [this volume]) belongs to the cross-linguistic inventory of AM-meanings. Although it is not very widespread (Guillaume 2016: 117-118; Ross, this volume), it is attested in $7.5 \%$ of the North American languages included in Dryer's sample (this volume), in the Pama-Nyungan language Kaytetye (Koch, this volume), and the Kiranti language Yamphu (Jacques et al., this volume). In the Pano language Chácobo the marker called 'counterdirectional' by Tallmann (this volume) can have a 'go and V and return' meaning, but can also be used to express circular motion and is thus not dedicated to the expression of returning after performing the verb event. A semantic feature of the 'go and V and return' affix combination is that it describes a motion event with two Goals: one of them is an interim point, while the other (the endpoint) coincides with the Source. This is relevant for the argument structure, since in theory either of the two Goal arguments could be expressed. However, in our data, if an overt Goal argument is present, this refers to the interim point and not to the endpoint of the motion event - probably because the latter is implied in the 'return' meaning provided by the suffix combination.

The $n d A$-suffix can be categorized as a "prior motion" marker in the classification of AM-markers of Levinson and Wilkins (2006), since the motion event precedes the verb event. The Tungusic languages thus fit the hierarchy proposed in Levinson and Wilkins (2006) and Guillaume (2016): if there is only one AM-marker in a language, this marker expresses prior motion and not concurrent or subsequent motion (12). Thus, prior motion is the most widespread type of AM cross-linguistically, confirmed by the cross-linguistic study of Ross (this volume), who finds it in $79 \%$ of the languages of his sample that have a morphological category of AM. 
(12) prior motion > concurrent motion > subsequent motion

A closely related category is Motion-cum-Purpose, where the motion event is "specifically aimed at the realization of the non-motion event" (Rose 2015: 121). This category has been primarily identified in languages of Mesoamerica that have distinct Associated Motion and Motion-cum-Purpose constructions (e.g. Haviland 1993; Zavala Maldonado 2000). In practice the distinction between Associated Motion expressing prior motion and Motion-cum-Purpose is quite subtle (cf. Guillaume 2006: 426; Ross, this volume), since in both cases the motion event precedes the verb event. In particular, in irrealis contexts such as imperatives or hortatives (which in the Tungusic languages very frequently carry the $n d A$-suffix) the two meanings are totally indistinguishable:



b. Ulch (spk_170725_nst_SkazkaDochka) muru-č- $i-n \quad$ as bi ร̌usto ga- $\boldsymbol{y d} \boldsymbol{d}-\boldsymbol{i}$ think-DUR-PRS-3SG now 1SG blueberry gather-AM-PRS.1SG '(She) thinks: Now, I'll go to gather blueberries / go and gather blueberries!'

There are numerous examples in the Tungusic corpora analysed here where the $n d A$-suffix has a clear sequential reading without a purposive nuance, e.g. (14a, b). In (14a) the sitting event is achieved after the scuffling movement across the floor, while in (14b) the next sentence makes it clear that the people did indeed search (and didn't only intend to do so), since they found the bear they were looking for.

a. Nanai (Bel'dy and Bulgakova 2012: 178, txt 16,60)

$\begin{array}{llll}\text { palan-dola } & \text { sisox } & \text { sisox sisox } \\ \text { floor-LOC } & \text { sisox } & \text { sisox sisox } \\ \text { goľ̌on } & & \text { ऊ̌uliz-či-ə-ni } \\ \text { stove } & & \text { in.front.of-ALL-OBL-POSS.3SG }\end{array}$

'She was scuffling on the floor: sisoh, sisoh, sisoh and then she sat at the fire.'

b. Lamunkhin Even (RDA_shatun_035)
oka:t ča:w-da-li-n
emie iak
river far-SIDE-PROL-POSS.3SG also.Y what
bi-h-ni ta-li mende-ne-če-l
be-NFUT-3SG DIST-PROL search-AM-PST.PTCP-PL
' $\ldots$ behind the river there is also something, there they went and searched.
\{There he found it.\}'

Such unambiguous sequential readings show that $-n d A$ cannot be defined as a dedicated motion-cum-purpose marker. However, there are also many examples in the Tungusic corpora which have a purposive reading rather than a specifically sequential reading. This can be clearly seen in those cases where the motion event is completed while the verb event is not (see [15a] for the independent use, [15b] for the pleonastic construction), as also discussed in detail by Jacques et al. (this volume).

$$
\begin{aligned}
& \text { a. Nanai (nmch_110815_ns_MatjJagody.069) } \\
& \text { simbi-a xaj balači-ndo-xam-bi-a un-ži }
\end{aligned}
$$


you-ACC what help-AM-PST-1SG-EMPH say-PRS

' $\{$ Why have you come here?\} - I've come to help you - she says.'

b. Udihe (Nikolaeva et. al. 2003: 80, txt 12, 48)

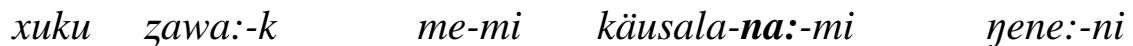

string take.PST-EXPR self-ACC strangle-AM-SIM.CVB go.PST-3SG

'She took a string and went to strangle herself. \{She found one place she wanted to hang herself, but it was a bad place.\}'

In (15a) the motion event ('come') has already been realized at the time of the speech act, while the verb event ('help') has clearly not been realized yet. In (15b) the motion event ('go') is being realized, while the verb event ('strangle herself') has not been started by the reference time (the next sentence shows that she failed to strangle herself). In both of these examples the $n d A$-suffix thus conveys a motion-cum-purpose ('go to V') meaning, and not an associated motion ('go and V') meaning. Interestingly, according to Alonso de la Fuente and Jacques (2018) the cognate marker in Classical Manchu differs in its function from what we find in the languages of our sample: it appears to lack the motioncum-purpose reading, having solely a sequential meaning, and can thus be regarded as a dedicated AM-marker. ${ }^{8}$

\section{The argument structure of $n d A$-verbs}

The arguments and adjuncts of motion verbs are expressed in Tungusic languages by a rich system of dedicated spatial case forms and by postpositional phrases (see Table 3 for an overview of the most important ones). Note that in this section (and in the paper overall), we ignore the core S and A arguments, which are irrelevant for our discussion.

1) In Nanai, there are four spatial cases. Location is expressed by the dative/essive

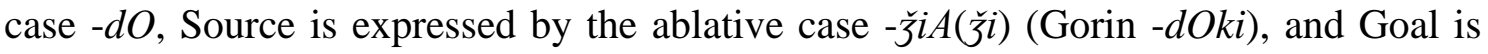
expressed by the allative case $-\check{c} i$. It shares this function with the postposition ba:roani. The "locative" case - $(d O) l A$ expresses Trajectory ('via, through, across') and also competes in some uses with all the other spatial cases. See Avrorin (1959: 177-183) for more detail.

2) The spatial case system of Ulch is similar to that of Nanai. In addition to the Nanai inventory, it has a dedicated prolative case (-ki) to express Trajectory. Unlike Nanai, it has no dedicated form to express Source: this is marked by the instrumental case -ži. The clitic =bA:n (the cognate of the Nanai postposition ba:roani) competes with the allative case - $t i$ in the Goal function; cf. Petrova (1936: 27-29, 43).

3) In Udihe, Location is expressed by the essive/dative - $d u$ (as in Nanai and Ulch). Source is expressed by the ablative -digi, Goal is expressed by the allative -tigi, Trajectory is expressed by the prolative - $l i$. The locative $-l A$ competes with the essive/dative case and with the allative case. See Nikolaeva and Tolskaya (2001: 118-127) for more detail.

4) The complement of spatial cases in Even differs from dialect to dialect. Static Location is mostly marked by the locative case $-(d u) l A$, although the dative case $-d u$ can also fulfil this function. Source is marked by the ablative case $-d u k$ and infrequently by the elative case -gičl-git, and Trajectory is marked by the prolative case $-(d u) l i$. The two dialects included here differ in the marking of Goal: in the Bystraja dialect, this is achieved mostly by the allative case $-t(A) k i$ or much more infrequently the allativelocative $-k l A$ and occasionally by the locative case. In the Lamunkhin dialect, in contrast, Goal is mostly marked by the locative case, with the allative being used much less frequently, and some rare examples of the dative occurring in this function as well.

\footnotetext{
${ }^{8}$ It is notable that related Gyalrongic languages of the Trans-Himalayan family also differ with respect to the degree of event integration, suggesting diachronic instability of this feature (Jacques et al., this volume).
} 
5) In Negidal, static Location is marked by the dative case $-d u$, while Goal is marked by both the locative $-(d u) l A$ and the allative $-t(i) k i$. As in Even, Source is marked by the ablative case $-d u k$, and Trajectory by the prolative $-(d u) l i$. The elative and allativelocative cases do not exist.

Table 3. The spatial case system in Tungusic

\begin{tabular}{|c|c|c|c|c|}
\hline & Location & Goal & Source & Trajectory \\
\hline Nanai & $-\mathrm{dO}$ & -či, ba:roani & $-\not \breve{i} \mathrm{~A} A \breve{i}$ & $-(\mathrm{dO}) 1 \mathrm{~A}$ \\
\hline Ulch & $-d u$ & $=\mathrm{bA}: \mathrm{n},-\mathrm{ti}$ & 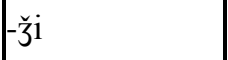 & $-\mathrm{ki},(-1 \mathrm{~A})$ \\
\hline Udihe & $-d u,(-1 A)$ & -tigi, (-1A) & -digi & $-1 i$ \\
\hline Even & $\begin{array}{l}-(d u) 1 A \\
(-d u)\end{array}$ & $\begin{array}{l}\text { Bystr.: -t(A)ki, (-klA) } \\
\text { Lam.: -(du)lA, (-t(A)ki) }\end{array}$ & -duk, (-gič/-git) & $-(\mathrm{du}) \mathrm{li}$ \\
\hline Negidal & $-d u$ & $-(\mathrm{du}) \mathrm{lA},-\mathrm{t}(\mathrm{i}) \mathrm{ki}$ & -duk & -(du)li \\
\hline
\end{tabular}

\subsection{Verb arguments vs. spatial arguments}

The argument structure of $n d A$-verbs is mixed. On the one hand, they can take the same arguments as the base verb, i.e. the verb without - ndA (highlighted in bold in the following examples). Thus, in (16a) the verb galo-ndo-gu- 'to go to search' takes the direct object $a g b i$ 'brother', as would the base verb galo-(gu)- 'to search', and in (16b) the reciprocal-marked verb tore-met-ne- 'to go to speak with someone' takes a comitative argument, as would the reciprocal-marked verb tore-met-.

$$
\begin{aligned}
& \text { a. Nanai (Bel'dy and Bulgakova 2012: 106, txt 11, 141) } \\
& \text { mi ag-bi galo-ndo-gu-əm-bi } \\
& \text { 1SG elder.brother-PREFL.SG search-AM-REP-ASSERT-1SG } \\
& \text { 'I'll go to search for my brother.' }
\end{aligned}
$$

b. Bystraja Even (AEI_ASA_muzej2_001)

$$
\text { Manja-gli tore-met-ne-ger }
$$

pers.name-COM speak-RECP-AM-IMP.1PL.INCL

'Let's go to speak with Manja!'

On the other hand, they can also take arguments which are typical of motion verbs (indicated by both bold and underlined font in the following examples): in (17a) the verb xupi-ndo- 'to come to play' takes the same allative-marked Goal argument $\sin -c ̌ i$ 'to you' as would the motion verb 'come', while in (17b) tay-na- 'to go and study' takes both an allative- and an ablative-marked argument, as would the motion verb 'go'. Neither xupi'to play', nor tay- 'to study' can take such arguments without the $n d A$-suffix, as can be seen in (19b) below, where the base form 'I studied' occurs with a dative-marked static Location. A similar case of the AM marker licensing the overt expression of a Goal argument is mentioned for the Nilotic language Shilluk (Payne, this volume). 
(17) a. Nanai (Avrorin 1986: 65, txt 13, 3)

sin- $\underline{\underline{c} \boldsymbol{i}} \quad$ xupi-ndo-xəm-bi

2SG-ALL play-AM-PST-1SG

'I've come to you to play.'

b. Bystraja Even (RMS_childhood.083)

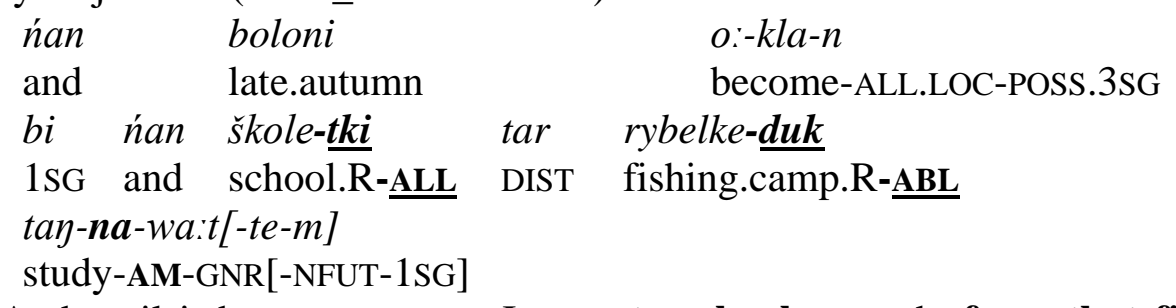

'And until it became autumn I went to school to study from that fishing camp.'

Interestingly, both the arguments typical of motion verbs (spatial arguments) and the arguments inherited from the initial verb stem (base verb arguments) can be expressed in one and the same clause; see (2) above and the examples in (18):

(18a) a. Negidal (Pakendorf and Aralova 2017, AET_grandmother: 73)

$\begin{array}{ll}\text { onin-mi } \quad \text { amin-mi } & \text { amin-yasa- } \beta \\ \text { mother-POSS.1SG father-POSS.1SG } & \text { father-DECES-POSS.1SG } \\ \text { tatkat-na:- } \beta \text { kan-t6a-tin } & \text { na:n-ma- } n \\ \text { study-AM-CAUS-PST-3PL } & \text { 3SG-ACC-3SG } \\ \text { nikolaevski-teki } & \text { učitel-du } \\ \text { geo.name- } \underline{\mathbf{L L}} & \text { teacher.R-DAT }\end{array}$

'My mother and father sent her to Nikolaevsk to study for teacher (i.e. to become a teacher).'

b. Lamunkhin Even (ZAS_naled_096)

$\begin{array}{llll}\text { djapk-is } & \text { stada-l } & \text { oran-tan } & \text { tar-tiki, } \\ \text { eight-ORD.Y } & \text { herd.R-PL } & \text { reindeer-POSS.3PL } & \text { DIST-ALL } \\ \text { tara-w } & \text { noyartan } & \text { tar-tiki } & \text { it-ne-wre-r } \\ \text { DIST-ACC } & \text { 3PL } & \text { DIST-ALL } & \text { see-AM-HAB[NFUT]-3PL }\end{array}$

'The reindeer of the eighth herd (went) there, and they (my father and brother) went there to watch them...'

c. Udihe (Nikolaeva et al. 2002: 45; txt 9, 24)

$\begin{array}{llll}\begin{array}{l}\text { zugdi-tigi } \\ \text { house-ALL }\end{array} & \begin{array}{l}\text { ge:-ne-gie } \\ \text { take-AM-REP.IMP }\end{array} & \begin{array}{l}\text { suese-we } \\ \text { axe-ACC }\end{array} & \begin{array}{l}\text { mo:-wo } \\ \text { tree-ACC }\end{array} \\ \begin{array}{l}\text { xua-yni-laga-mi } \\ \text { cut-AM-PURP-PREFL }\end{array} & & & \\ & & \end{array}$

'Go home to get an axe to cut down the tree.'

d. Ulch (BD_legend1)

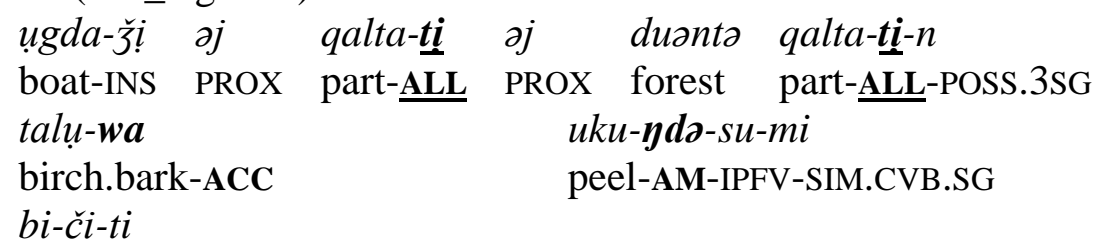

$b i$-či- $t i$

be-PST-3PL 


\section{'(They) used to go by boat to this forest side to peel the birch-bark.'}

There are no evident restrictions on spatial arguments, as can be seen from the elicited example from Nanai (19a). Here, all the possible types of spatial roles (Source, Goal, and Trajectory) are expressed within one and the same clause. Similarly, in the text examples in (17b) above and (19b) both Source and Goal are expressed.

a. Nanai (elicited, NCHB)

$$
\begin{array}{lllll}
\text { aktə-sal } & \text { exon-žia } & \text { xoton-či } & \text { goj } & \text { pokto-la } \\
\text { woman-PL } & \text { village-ABL } & \text { town-ALL } & \text { other } & \text { road-LOC } \\
\text { amtaka-wa } & \text { xodasi-na-xa-či } & & & \\
\text { berry-ACC } & \text { sell-AM-PST-3PL } & & & \\
\text { The } & &
\end{array}
$$

'The women went to sell berries from the village (Source) to the town (Goal) by another road (Trajectory).'

b. Bystraja Even (EIA_leaving_Twajan_117)

$\begin{array}{lll}\text { Ketačan-gič=kal } & \text { nan ewe-ski } & \text { tay-na-ri-wu } \\ \text { geo.name-ELAT=COORD } & \text { and PROX-ADV.ALL } & \text { read-AM-PST-1SG } \\ \text { Esso:-tki, } & \text { Esso:-du } & \text { nan } \\ \text { geo.name-ALL } & \text { geo.name-DAT } & \text { and } \\ \text { taya-dza:n-ni-wu } & & \text { mudaka-kla-n } \\ \text { read-DUR-PST-1SG } & & \text { finish-ALL.LOC-POSS.3SG }\end{array}$

'And from Ketachan I came here to Esso to attend school, and in Esso I studied until the end.'

To a certain extent the AM-suffix in the Tungusic languages thus resembles an applicative, since it allows the addition of an argument that isn't licensed by the lexical verb on its own; cf. Mithun (2002: 73): "Prototypical applicatives are derivational processes within the verbal morphology that add a participant to the set of core arguments. The added argument usually represents a semantic recipient, beneficiary, instrument, associate, direction, or location...". However, in contrast to true applicatives, there is no promotion of an oblique argument to a core argument in the AM construction, since the case-marking of all the arguments remains the same as in non-AM constructions: Goals are marked with allative or locative case, and the base verb arguments carry the casemarking licensed by the lexical verb.

Spatial arguments are overtly expressed in c. 15-20\% of the independent $n d A$ constructions (for pleonastic constructions see Section 4.2), as shown in Table 4. Ulch expresses spatial arguments more frequently than do the other languages; however, this difference is not statistically significant.

Table 4. Spatial arguments with $n d A$-verbs (independent constructions)

\begin{tabular}{|l|r|r|r|}
\hline \multicolumn{1}{|c|}{ Language } & $\begin{array}{c}\text { With } \\
\text { spatial } \\
\text { arguments }\end{array}$ & $\begin{array}{c}\text { All } \\
\text { independent }\end{array}$ & $\begin{array}{c}\text { \% with spatial } \\
\text { arguments }\end{array}$ \\
\hline Nanai & 14 & 96 & $15 \%$ \\
\hline Ulch & 15 & 68 & $22 \%$ \\
\hline Udihe & 18 & 135 & $13 \%$ \\
\hline Lamunkhin Even & 8 & 50 & $16 \%$ \\
\hline
\end{tabular}




\begin{tabular}{|l|r|r|r|}
\hline Bystraja Even & 24 & 138 & $17 \%$ \\
\hline Negidal & 17 & 114 & $15 \%$ \\
\hline
\end{tabular}

Interestingly, non-spatial arguments typical of motion verbs can also be expressed with $n d A$-verbs. Even though in a judgement task speakers of Ulch were doubtful of examples in which the role "Transport" (marked with the instrumental case [20a]) was expressed (20b), similar examples are found in the Ulch narrative corpus, e.g. (18d) above and (21a) below. Such examples are also found in the Bystraja Even (21b) corpus:

a. Ulch (elicited, IPR)

xusa pikta pojez-ร̌i yan-i-n

male child train.R-INS go-PRS-3SG

'The boy goes by train.'

b. Ulch (elicited, IPR)

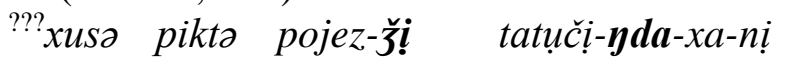

male child train.R-INS learn-AM-PST-3SG

'The boy went to study by train.'

a. Ulch (spk_171112_Biografia)

Kiž̆i=bən murin-̌̆i gala-ydo-su-xə

geo.name=ALL horse-INS search-AM-IPFV-PST

'They used to go for it (lit. go to search for it) to the lake Kizi by horse.'

b. Bystraja Even (GIK_life_Anavgaj_183)

motocikli-č eje-ne-dzi-ru mura-l-ba

motorcycle.R-INS look-AM-FUT-1PL.EXCL horse-PL-ACC

'We will go to look at the horses by motorbike.'

\subsection{Argument structure in different syntactic constructions}

Although it is possible to express spatial arguments overtly in AM-constructions, it is nevertheless the verb argument that is expressed more commonly. In Table 5, we summarize the occurrences of different kinds of overt arguments found in independent $n d A$-constructions with transitive base verbs. These constructions have at least two possible argument slots (along with that of the subject), one for the spatial argument and one for the verb argument (i.e. the direct object in this case), and in theory both could be filled equally. However, in the corpora the verb argument is overtly expressed three to nine times more frequently than the spatial argument. ${ }^{9}$ The greatest difference is attested in Udihe and Nanai, the smallest is found in Ulch. Importantly, the co-expression of spatial arguments and verb arguments is very rare in all the languages, i.e. usually only one slot is filled, a point we come back to below.

Table 5. The argument structure of $n d A$-verbs (independent constructions with transitive verbs)

\footnotetext{
${ }^{9}$ Quite frequently neither argument is expressed, since argument-dropping is common in Tungusic languages.
} 


\begin{tabular}{|c|c|c|c|c|c|}
\hline Language & $\begin{array}{l}\text { Only spatial } \\
\text { argument }\end{array}$ & $\begin{array}{l}\text { Only verb } \\
\text { argument } \\
\text { (O) }\end{array}$ & $\begin{array}{l}\text { Spatial argument } \\
\text { and verb } \\
\text { argument }\end{array}$ & $\begin{array}{l}\text { No } \\
\text { argument }\end{array}$ & $\begin{array}{l}\text { Ratio verb/ } \\
\text { spatial } \\
\text { argument }\end{array}$ \\
\hline Nanai & 5 & 46 & 1 & 13 & 7.8 \\
\hline Ulch & 6 & 28 & 3 & 15 & 3.4 \\
\hline Udihe & 3 & 58 & 4 & 43 & 8.9 \\
\hline $\begin{array}{l}\text { Lamunkhin } \\
\text { Even }\end{array}$ & 3 & 24 & 3 & 12 & 4.5 \\
\hline $\begin{array}{l}\text { Bystraja } \\
\text { Even }\end{array}$ & 3 & 31 & 2 & 36 & 6.6 \\
\hline Negidal & 4 & 35 & 6 & 39 & 4.1 \\
\hline
\end{tabular}

Interestingly, $n d A$-constructions with intransitive base verbs occur more frequently with overt spatial arguments than do $n d A$-constructions with transitive base verbs (Table 6), suggesting a potential preference for overtly expressing only one of the two possible arguments per verb; this effect is significant for Nanai, Udihe and Bystraja Even (2-tailed Fisher's exact test, $\mathrm{p}<0.05$ ). This might be an indication that the availability of the transitive verb argument 'blocks' expression of the spatial argument unless the speaker chooses to give the motion event equal or more discourse prominence by overtly expressing its argument. We return to the choice of foregrounding the motion event over the verb event in the discussion below (Section 6).

Table 6. Spatial arguments with transitive vs. intransitive verbs (independent constructions)

\begin{tabular}{|l|r|r|r|r|r|r|}
\hline & \multicolumn{3}{|c|}{ Transitive verbs } & \multicolumn{3}{|c|}{ Intransitive verbs } \\
\hline Language & $\begin{array}{c}\text { Spat } \\
\text { arg* }\end{array}$ & \multicolumn{1}{|c|}{$\begin{array}{c}\text { No spat } \\
\text { arg }\end{array}$} & $\begin{array}{c}\text { \% with } \\
\text { spat arg }\end{array}$ & $\begin{array}{c}\text { Spat } \\
\text { arg }\end{array}$ & $\begin{array}{c}\text { No spat } \\
\text { arg }\end{array}$ & $\begin{array}{c}\text { \% with } \\
\text { spat arg }\end{array}$ \\
\hline Nanai & 6 & 59 & $9 \%$ & 6 & 14 & $30 \%$ \\
\hline Ulch & 9 & 43 & $17 \%$ & 5 & 9 & $36 \%$ \\
\hline Udihe & 7 & 101 & $6 \%$ & 11 & 8 & $58 \%$ \\
\hline $\begin{array}{l}\text { Lamunkhin } \\
\text { Even }\end{array}$ & 6 & 36 & $14 \%$ & 0 & 5 & $0 \%$ \\
\hline $\begin{array}{l}\text { Bystraja } \\
\text { Even }\end{array}$ & 5 & 67 & $7 \%$ & 14 & 31 & $31 \%$ \\
\hline Negidal & 10 & 74 & $12 \%$ & 5 & 15 & $25 \%$ \\
\hline
\end{tabular}

*spat arg = spatial argument

In pleonastic constructions the motion event is expressed twice: once via the motion verb and once via the AM-suffix on the base verb, be this coded as a finite verb (in the echo construction) or as a converb. It is thus possible that the pleonastic 
constructions contain more overt spatial arguments than independent AM constructions, which have only one verb that expresses both the verb event and the motion event. As can be seen in Table 7, this is indeed the case at least for some of the languages under consideration (for examples of the converbial construction with overt spatial argument see 22a and 23a below; for examples of the echo construction with overt spatial argument see 22b and 24a): in all languages except Ulch and Negidal pleonastic constructions code spatial arguments significantly more frequently than do independent constructions (2tailed Fisher's exact test, $\mathrm{p}<0.05)$.

a. Lamunkhin Even (AEK_reindeer_herd_011)

$\begin{array}{lll}\text { ejmu } & \text { no:-n } & \text { kuya-l-čal } \\ \text { mother.POSS.1SG } & \text { younger.sib-POSS.3SG } & \text { child-PL-COM } \\ \text { mut-tule } & \text { ńo:-wre-ri-n } & \text { deremket-ne-mi } \\ \text { 1PL-LOC } & \text { exit-HAB-PST-3SG } & \text { rest-AM-SIM.CVB } \\ \text { y mother's younger sister [...] also went to us [...] with her children to rest. }\end{array}$

'...my mother's younger sister $[. .$.$] also went to us [. .$.$] with her children to rest.'$

b. Udihe (Nikolaeva et al. 2002: 70, txt 12, 77)

$\begin{array}{lll}t i: & \text { emne-gde } & \text { yene: }-n(i) \\ \text { DIST } & \text { once-FOC } & \text { go.PST-3SG } \\ \text { ba-ixi } & u l i & \text { gay-na-gi-e- } n(i) \\ \text { place-ALL } & \text { water } & \text { fetch-AM-REP-PST-3SG } \\ \text { One day (the mother) went outdoors to fetch some water.' }\end{array}$

The data on overtly expressed verb arguments, in contrast, are rather less clear: although both pleonastic and independent constructions express the verb event via the single $n d A$-verb, so that one wouldn't expect any difference in argument expression, there is variation between the languages. Only in Nanai, Bystraja Even, and Negidal do we find roughly equal amounts of overtly expressed verb arguments in pleonastic and independent constructions, as expected. In Ulch and Lamunkhin Even, in contrast, the verb event is expressed significantly more often in independent constructions than in pleonastic ones (2-tailed Fisher's exact test, $\mathrm{p}<0.05$ ), whereas in Udihe it is expressed significantly less frequently in independent constructions (2-tailed Fisher's exact test, $\mathrm{p}<0.05)$. These patterns do not correlate with the proportion of converbial vs. echo pleonastic constructions, as a comparison with Table 2 shows. What factors determine the overt expression of verb arguments is thus still unclear.

Table 7. Spatial arguments in independent and pleonastic constructions

\begin{tabular}{|l|r|r|r|r|}
\hline & \multicolumn{2}{|c|}{ Pleonastic with... } & \multicolumn{2}{c|}{ Independent with... } \\
\hline Language & Spatial arguments & Verb arguments & Spatial arguments & Verb arguments \\
\hline Nanai & $21(50 \%)$ & $23(55 \%)$ & $14(15 \%)$ & $50(52 \%)$ \\
\hline Ulch & $8(27 \%)$ & $8(26 \%)$ & $14(21 \%)$ & $34(50 \%)$ \\
\hline Udihe & $18(35 \%)$ & $34(64 \%)$ & $18(16 \%)$ & $63(47 \%)$ \\
\hline $\begin{array}{l}\text { Lamunkhin } \\
\text { Even }\end{array}$ & $20(40 \%)$ & $10(20 \%)$ & $8(16 \%)$ & $28(56 \%)$ \\
\hline $\begin{array}{l}\text { Bystraja } \\
\text { Even }\end{array}$ & $16(57 \%)$ & $7(25 \%)$ & $24(17 \%)$ & $35(25 \%)$ \\
\hline
\end{tabular}




\begin{tabular}{|l|r|r|r|r|}
\hline Negidal & $11(26 \%)$ & $16(38 \%)$ & $17(15 \%)$ & $45(40 \%)$ \\
\hline
\end{tabular}

In pleonastic constructions with an overt spatial argument, this might be governed by the motion verb or the $n d A$-verb. Without in-depth syntactic analysis it is not easy to distinguish between these options, and it might even be the case that the spatial argument is governed by both verbs. Based simply on word order and distance between the spatial argument and the motion verb vs. $n d A$-verb, it would appear that both options are indeed available $(23 a, b)$.

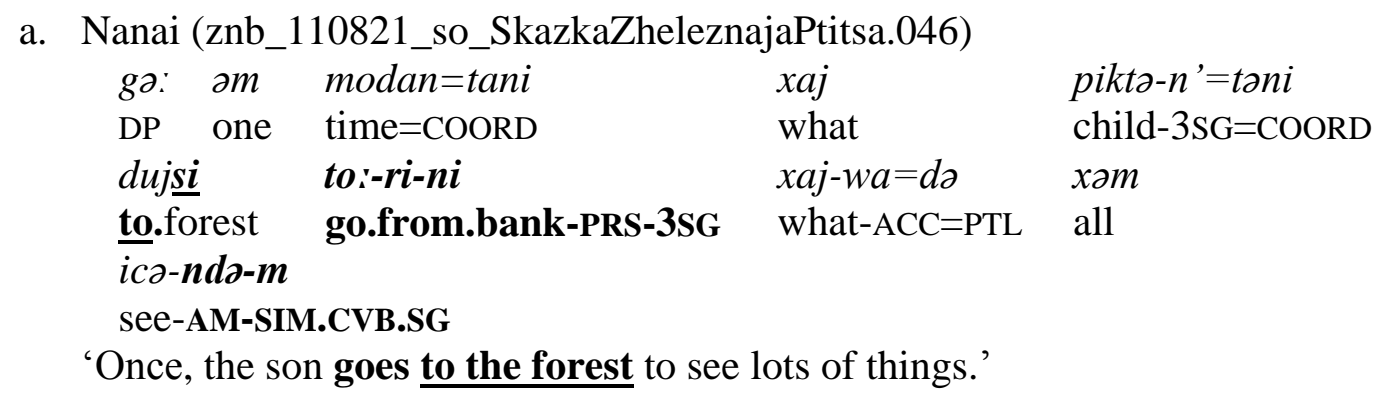

b. Bystraja Even (NIG_shkola_remesel_1_293)

$\begin{array}{lll}\text { yen-de-ku} & \text { gu:n-e-m } & \text { čas } \\ \text { go-PURP-1SG } & \text { say-NFUT-1SG } & \text { PTL } \\ b i & \text { čepuki-w } & \text { ayani-ldewu... } \\ \text { 1SG } & \text { boots.R-ACC } & \text { sew-NMLZ } \\ \text { unta-l-ba } & \text { ayani-ldewun-teki } & \text { upkut-ne-de-ku } \\ \text { fur.boots-PL-ACC } & \text { sew-NMLZ-ALL } & \text { learn-AM-PURP-1SG }\end{array}$

'And I said "well, let me go, let me go to study where they sew boots, where they sew fur boots".'

In (23a) the Goal argument dujsi 'to the forest' precedes the motion verb to:- 'go from the riverbank' and is separated from the $n d A$-verb by the verb argument 'a lot of things' and by the motion verb. It is thus arguably the motion verb that triggers the overt Goal marking here. In contrast, in (23b) the Goal argument is adjacent to the $n d A$-verb and is separated from the motion verb by the self-corrected speech error; arguably, in this case it is the $n d A$-verb that governs the Goal argument. Judging purely from such very superficial considerations (by simply counting constructions where the spatial argument is closer to the motion verb than the $n d A$-verb and vice versa), it would appear that in pleonastic constructions the spatial argument is more frequently governed by the motion verb than by the $n d A$-verb (this can also be seen in [22a-b], where it is more likely that the spatial argument is governed by the motion verb). However, this conclusion needs to be ascertained with more detailed investigations.

In pleonastic constructions, the motion verb and the $n d A$-verb can be syntactically independent, as shown by $(24 a-c)$. In the echo construction in (24a) the spatial argument is repeated in near-identical form: since in Negidal both the allative and the locative can mark Goal arguments, as outlined in Section 4 above, okin-tiki-j and okin-dula-j both mean 'to my older sister'. Thus here the clause 'go to my older sister' is repeated using two different verbs. Such independence of the two verbs is possible not only with echo constructions, but also with converbial pleonastic constructions, as shown in (24b) and $(24 c)$.

(24) a. Negidal (Pakendorf \& Aralova 2017, APN_two_sisters: 82) okin-tiki-j gənə-mtco-lti gun-ə-n 
older.sister-ALL-PREFL.SG go-SBJV-1PL.INCL Say-NFUT-3SG

okin-dula-j

older.sister-LOC-PREFL.SG

itce-na-mtca-lti

see-AM-SBJV-1PL.INCL

'... we should go to my sister, we should go see my sister.'

b. Lamunkhin Even (SPK_oxota_047)

$\begin{array}{lllr}\text { iril-du ... } & \text { amm-u } & \text { ia-la } & \text { hor-ger-e-n } \\ \text { summer-DAT } \ldots & \text { father-POSS.1SG } & \text { HESIT-LOC } & \text { go-HAB-NFUT-3SG } \\ \text { stada-du } & \text { orolčimia-l-du } & \text { kömölöh-ne-mi } \\ \text { herd.R-DAT } & & \text { reindeer.herder-PL-DAT } & \text { help.Y-AM-SIM.CVB }\end{array}$

'In summer my father goes to whatchamallit, he goes to the herd to help the reindeer herders.'

c. Nanai (Avrorin 1986: 83, txt 18)

\begin{tabular}{|c|c|}
\hline  & $\begin{array}{l}\text { tua-ri-ndo-gu-mori } \\
\text { winter-VBLZ-AM-REP-SIM.CVB.PL }\end{array}$ \\
\hline 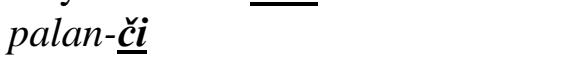 & $i-x \partial-c ̌ i$ \\
\hline floor- $\underline{\mathbf{A L L}}$ & enter-PST-3PL \\
\hline
\end{tabular}

In (24b) the Goal argument of the motion verb is first introduced via the hesitative iak (literally 'what'), marked with the locative case. It is repeated in the subordinate clause with the dative-marked noun stada-du 'to the reindeer herd', where it is governed by the converb kömölöh-ne-mi 'going to help'. (Note that the dative case-marking on orolčimya$l$ 'reindeer herders' is governed by the base verb kömölöh- 'to help', and not by the motion event.) As described above, in Lamunkhin Even the dative case is occasionally used to mark Goal arguments in addition to the more frequent locative case, accounting for the variation in case marking on the hesitative and lexical noun. Example (24c) from Nanai illustrates the converbial construction with two different spatial arguments-one governed by the converb ('to the house') and the other governed by the finite verb ('to the cellar'). The linear position seems to reflect semantic differences: 'the house' is a more general location (the rats came to the house to spend the winter there), 'the cellar' is a more specific one (they entered into this particular part of the house). Such examples provide evidence for the high degree of autonomy of the components of the pleonastic construction.

\subsection{Competition between spatial argument and verb argument}

The motion event and the verb event sometimes share an argument (other than the subject, which is always shared). The most prominent case is when the goal of the motion event coincides with the location of the verb event. It is an open question which coding strategy is chosen in this case: that of the motion event (Goal) or that of the verb event (Location).

As seen in examples (25a) and (25b) from Ulch, both options are available. In example (25a) the pronoun 'that' is marked with the essive/dative case as the location of the verb event ('to set a net in that place'). In (25b), the noun 'hill' is marked with the allative case as the goal of the motion event ('to go to the hill'). Coding of both Goal and Location is not attested and is rejected by speakers (25c).

$$
\begin{aligned}
& \text { a. Ulch (lpd_170626_SluchajNaRybalke) }
\end{aligned}
$$

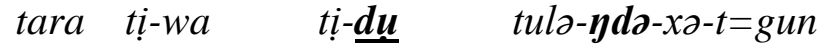

$$
\begin{aligned}
& \text { then DIST-ACC DIST-DAT set.net-AM-PST-3PL=PTL }
\end{aligned}
$$


'Then they went to set there a net for this (fish).' - Location (the verb event argument)

b. Ulch (elicited, GIP)

xurəm=bon boqto-wa ga-yda-xa-n

hill=ALL pine.nut-ACC gather-AM-PST-3SG

'(He) went to the hill to gather pine nuts.' - Goal (the spatial argument)

c. Ulch (elicited, GIP)
*xurəm=bon boqto-wa
$t i-d u$
ga-yda-xa-n
hill=ALL pine.nut-ACC
DIST-DAT gather-AM-PST-3PL=PTL

expected: ' $(\mathrm{He})$ went to the hill to gather pine nuts there.'

Nevertheless, in general it is the Goal argument that tends to be expressed, not the Location. For example, an elicitation task conducted with Nanai and Ulch speakers shows that with the verb 'study' only the encoding of the Goal argument was accepted (27a), and examples with Location-encoding were rejected or judged as dubious (27b) (cf. [26], which illustrates Location-encoding in the absence of the $n d A$-suffix). Although overt expression of Location was judged acceptable with the verb 'be, live' (27c), in the Nanai text corpus only an example with overtly expressed Goal was found.

(26) Nanai (elicited, NCHB)

xoton- $\underline{\text { do }}$ tačeo-če-xa-ni / baľ̌e-xa-ni

town-DAT learn-DUR-PST-3SG / live-PST-3SG

'(He) studied / lived in the town.' =Location

a. Nanai (elicited, NCHB)

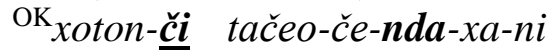

town-ALL learn-DUR-AM-PST-3SG

'(He) went to the town to study.' = Goal

b. Nanai (elicited, NCHB)

${ }^{? ?}$ xoton-do tačeo-če-nda-xa-ni

town-DAT learn-DUR-AM-PST-3SG

expected: '(He) went (away) to study in the town.' =Location

c. Nanai (elicited, NCHB)

goj boa-du baľ̌e-nda-xa-ni

other place-DAT live-AM-PST-3SG

'He went away to live in some other place.' =Location

The compatibility of the $n d A$-marked verb $b i$ - 'to be, live' with Location arguments is also demonstrated by data from Bystraja Even: in the corpus there are two examples where the $n d A$-verb bi(d)ne- takes an overtly expressed Goal, e.g. (28a), and one example where it takes an overtly expressed Location (28b). It is possible that the Location argument in (28b) is triggered by the progressive suffix on the verb, which emphasizes the duration of the event and is thus more compatible with static location.

\footnotetext{
a. Bystraja Even (JIP_RME_razgovor_454)

e-te-m gu:n-ni bi kuren=de Maksim-teki

NEG-FUT-1SG say[NFUT]-3SG 1SG on.purpose=PTL pers.name-ALL

bi-ne-dzi-m
} 
be-AM-FUT-1SG

'No, she said, I will go on purpose to Maksim to live.' =Goal

b. Bystraja Even (TEB_childhood_042)

potom ewe-ski em-ni-ten,

then.R PROX-ADV.ALL come-PST-3PL

nan e-du bi-d-ne-ri-ten

and PROX-DAT be-PROG-AM-PST-3PL

'Then they came here to live here.' = Location

Text examples with Location arguments are much less common than those with overt Goal arguments, as summarized in Table 8 (only independent constructions were taken into account). Since in Udihe and especially Lamunkhin Even one and the same case form (the locative) can encode both Goal and Location arguments, as outlined above (see Table 3), it is not clear in all cases which of these is encoded.

Table 8. Goal-encoding vs. Location-encoding in independent constructions

\begin{tabular}{|l|r|r|r|r|}
\hline Language & Goal & Location & Unclear & $\begin{array}{c}\text { \% of Location among } \\
\text { clear examples }\end{array}$ \\
\hline Nanai & 14 & 0 & 0 & $0 \%$ \\
\hline Ulch & 14 & 1 & 3 & $7 \%$ \\
\hline Udihe & 17 & 2 & 7 & $11 \%$ \\
\hline Lamunkhin Even & 4 & 2 & 0 & $33 \%$ \\
\hline Bystraja Even & 24 & 4 & 4 & $14 \%$ \\
\hline Negidal & 16 & 0 & 1 & $0 \%$ \\
\hline
\end{tabular}

In some cases, the direct object of the base verb can be perceived as the Goal of the motion event, opening up a choice of which of these roles to encode, Theme/Patient or Goal. As shown in (29) taken from the Negidal corpus, it is indeed possible for speakers to encode the Goal argument rather than the Theme. However, there are only two examples of this kind in the corpora used for this study, both produced by the same speaker (see [24a] above for the other example).

(29) Negidal (Pakendorf \& Aralova 2017, APN_zabludilisj: 13)

$\begin{array}{lll}\text { gə taj } u j & \text { bəjə-l } & \text { gənə-tca:-tki-tin } \\ \text { DP DIST recently } & \text { person-PL } & \text { go-PST.PTCP-ALL-3PL } \\ \text { itce-na:-gaj } & & \text { gun-ə- } n \\ \text { see-AM-IMP.1PL.INCL } & \text { say-NFUT-3SG }\end{array}$

"'Let's go see that place where those people recently went to", she says.'

In example (29) the place recently visited by 'those people' is marked with the allative case expected for a Goal argument instead of the accusative case expected for the Theme of 'see'. The choice of encoding the Goal rather than the Theme might here be due to the 
importance of the motion event in this case, ${ }^{10}$ since the principal participants in the narrative spent a lot of time walking to the place referred to here and ultimately got lost. We discuss a similar example of choice of encoding triggered by the weight accorded to the motion event, taken from Negidal's close sister Evenki, in the discussion in Section 6.

Some arguments are semantically compatible both with the motion event and with the verb event, for example when both events have a valency for the Goal argument. In this case, there is competition between the interpretation of the Goal as argument of the motion event and the Goal as argument of the verb event. These uses are quite marginal, since $-n d A$ is compatible with only very few motion verbs; ${ }^{11}$ however, examples such as (30) are possible. Elicitation tasks conducted with Nanai speakers show that in (30)where it is the AM-suffix that provides the meaning of 'arrived' - only the interpretation of Naikhin being the argument of the motion event is possible. No such examples are found in the texts analysed here.

Nanai (elicited, SSB)

$$
\text { Najxin-či solo-nda-xa-či }
$$

geo.name-ALL go.upriver-AM-PST-3PL

'(They arrived) at Naikhin to go (from there) upriver.'

*'(They arrived) to go upriver to Naikhin.'

\section{Differences in AM-constructions between Tungusic languages}

As shown by the data from the five more or less closely related languages included in this study, there are small but notable differences in AM constructions between the individual lects. We summarize these differences in Table 9; details were provided in the preceding sections. No obvious clustering of the lects by their genealogical or areal groupings can be discerned (cf. Figures 1 and 2).

Table 9. Summary of differences in AM constructions in six Tungusic lects

\begin{tabular}{|l|l|}
\hline Parameter & Language hierarchy \\
\hline Frequency of use & Udihe >> Nanai, Bystraja Ev., Negidal > Ulch, Lamunkhin Ev. \\
\hline$\%$ pleonastic constructions & Lamunkhin Ev. > Ulch, Nanai, Udihe, Negidal > Bystraja Ev. \\
\hline$\%$ echo (over all pleonastic) & $\begin{array}{l}\text { Bystraja Ev. >> Negidal, Udihe >> Ulch, Lamunkhin Ev., } \\
\text { Nanai }\end{array}$ \\
\hline Ratio verb arg/spat arg* & $\begin{array}{l}\text { Udihe > Nanai > Bystraja Ev. > Lamunkhin Ev., Negidal > } \\
\text { Ulch }\end{array}$ \\
\hline
\end{tabular}

${ }^{10}$ It should be noted that there is a possibility that the allative case is simply a non-standard means of marking the Theme: although this speaker produced many more accusative-marked Theme arguments, she did produce two examples where the Theme of the simple verb itce- 'to see' was marked with the allative case (in addition to the two examples mentioned in the text where the allative-marked Theme was the argument of AM-marked 'go and see').

${ }_{11}$ We find motion verbs occurring with the AM-suffix only in the corpora of the Southern Tungusic languages Nanai, Ulch, and Udihe; these are verbs of manner of motion (e.g. 'to run', 'to float', 'to jump') and verbs expressing the trajectory of motion (e.g. 'to pass', 'to enter', 'to reach'). In the spontaneous text examples, the $n d A$-suffix doesn't add any further motion event or any specification of trajectory, in contrast to the elicited example (30), where the motion event that precedes the 'going upriver' is expressed by the AM-marker. 


\begin{tabular}{|l|l|}
\hline $\begin{array}{l}\% \text { intr with spat arg/ } \\
\% \text { trns with spat arg }\end{array}$ & $\begin{array}{l}\text { Udihe }>>\text { Bystraja Ev. > Nanai > Ulch, Negidal }>>\text { Lamunkhin } \\
\text { Even }\end{array}$ \\
\hline $\begin{array}{l}\% \text { spat arg pleonastic/ } \\
\% \text { spat arg independent }\end{array}$ & Bystraja Ev., Nanai > Lamunkhin Ev., Udihe > Negidal > Ulch \\
\hline
\end{tabular}

$* \arg =\operatorname{argument} ;$ spat $=$ spatial $; \%=$ proportion of uses $;$ Ev. $=$ Even

Udihe stands out in making extensive use of the $n d A$-suffix overall, with nearly three times as many examples counted in the published text collections than what we found in Nanai and Bystraja Even, and nearly five times as many examples as those found for Ulch and Lamunkhin Even. The frequency of the individual constructions differs, too, with independent constructions predominating heavily in Bystraja Even, and pleonastic constructions making up half of all examples in Lamunkhin Even. In the other languages, pleonastic uses comprise about one quarter to one third of all examples. There are also differences in the preferred subtype of pleonastic construction, with Nanai, Ulch, and Lamunkhin Even demonstrating a strong preference for converbial constructions and Bystraja Even having a marked preference for echo constructions. The frequency of pleonastic converbial constructions in Lamunkhin Even might have increased through contact influence from the neighbouring Turkic language Sakha (Yakut), since in this language finite motion verbs with simultaneous converbs of the lexical verb express ' $g o$ to $\mathrm{V} / \mathrm{go}$ and $\mathrm{V}^{\prime}$, as in (31):

$$
\begin{aligned}
& \text { Sakha (Pakendorf field data, XatR_274) } \\
& \text { dzaxtal-lar bari ot-tu: } \quad \text { bar-büt-tar } \\
& \text { woman-PL all hay-VBLZ.CVB go-PST.PTCP-PL } \\
& \text { '...the women had all gone to make hay.' }
\end{aligned}
$$

There are also fine-grained differences in the argument structure between the lects. While all the lects overtly express the verb argument more frequently than the spatial argument in independent transitive constructions, this preference is more pronounced in Udihe and Nanai than in Lamunkhin Even, Negidal, and especially Ulch. Furthermore, in all lects the proportion of overtly expressed spatial arguments with intransitive AM-verbs is higher than with transitive AM-verbs - with the exception of Lamunkhin Even, where no intransitive $n d A$-verbs occur with an overtly expressed spatial argument. (It should be noted, however, that the frequency of intransitive verbs is overall rather low.) Finally, whereas the proportion of overtly expressed spatial arguments is higher in pleonastic constructions than in independent ones in all lects, the difference is far more pronounced for Bystraja Even and Nanai than it is for Negidal or Ulch - in accordance with the fact that in these languages spatial arguments tend to be less frequently expressed than verb arguments.

\section{Discussion and conclusions}

To summarize, in the six Tungusic lects investigated for this study, the single AMmarker is used with various meanings, not only 'go and V' and 'go in order to V', but also 'come and V', 'come in order to $\mathrm{V}$ ', and-in conjunction with the suffix $-s V$ - 'go and $\mathrm{V}$ and return' (a combination that appears to have grammaticalized into a distinct AM-marker in Bystraja Even and Negidal, as discussed in Section 4.2). The $n d A$-verb occurs in three different constructions in the Tungusic languages: 1) as the sole verb in independent constructions, or accompanying a verb of motion in pleonastic constructions, where the $n d A$-verb can 2) either be finite ('echo' constructions) or 3) a converb. There are pronounced differences in frequency of these different constructions between the 
languages examined here, although independent constructions tend to be preferred by most. The languages also differ in their overall frequency of use of the $n d A$-suffix, but it is infrequent everywhere in comparison to other derivational affixes attested in the same languages. It is hard to evaluate the frequency of use of the AM-suffix in the Tungusic languages in a cross-linguistic perspective, since most studies to date do not mention frequency of use, rather focusing on the form and function of the markers found in a particular language. Among the few exceptions are Koch (this volume), who counts 240 AM forms in Kaytetye in 2870 sentences and Rose (2015), whose count of the two most frequent AM markers in Mojeño Trinitario is higher than what we find in the languages investigated here with the exception of Udihe (cf. footnote 10 above). For Mparntwe Arrernte Wilkins (1991: 215) counts between 0-36\% of AM-verbs (i.e. in some texts a full third of all verbs carry an AM-marker), while O'Connor (2004) counts 234 examples of the two morphemes with a translocative meaning in 22 texts of Lowland Chontal (without giving a precise count for the two morphemes with a cislocative meaning). While it is of course difficult to compare counts based simply on the number of texts (which can vary enormously in length), in Udihe, the language in our sample showing the highest frequency of the $n d A$-suffix, we find 188 examples in 42 texts. Thus, based on the scanty information available to us it would seem that the AM-suffix in the Tungusic languages investigated here is not only infrequent in comparison to other derivational morphemes within the languages, but also in comparison to other languages. ${ }^{12}$

Intriguingly from a cross-linguistic point of view, in all the languages studied here $n d A$-verbs can express not only the argument of the base verb, but also the spatial argument, and occasionally both. While overall overtly expressed verb arguments occur more commonly than overtly expressed spatial arguments, in most languages intransitive verbs and pleonastic constructions occur with spatial arguments more frequently than do independent transitive constructions. This might be an indication that there is a constraint towards expressing only one argument per verb, so that the spatial argument is 'blocked' by the verb argument in independent constructions with transitive base verbs. In contrast, constructions with intransitive base verbs - where there is no verb argument that could block expression of the spatial argument - and pleonastic constructions, where the spatial argument can be governed not only by the $n d A$-verb, but also by the semantically redundant motion verb, would offer more free slots for overt spatial arguments.

However, while formal considerations indeed seem to play a role in the choice of argument encoding, this is clearly not the whole story. Rather, as we argue here, this choice seems to be guided partly by which event is being foregrounded, as shown in examples (28a), (28b), and (29). In (28a), with the location of living being marked as the Goal (carrying allative case), the entire event is still in the future, and emphasis is on the move from the current living space to the new one. In (28b), in contrast, where the location of living is marked as the Location (with the dative case), the entire event is in the past and the focus is on the verb event, the duration of which is expressed by the progressive aspect. Similarly, as mentioned above, in the Negidal example (29) the focus of the narrative is on motion, on walking towards the place that other people had gone to, but never reaching it and getting hopelessly lost. The motion event is thus foregrounded here, which might account for the choice of encoding the direct object of the verb event not as Theme (which is the most common encoding chosen for objects of AM-marked 'see' in the languages included here), but as Goal.

The importance of discourse prominence of the motion event vs. the verb event in the choice of argument encoding in Tungusic languages is shown particularly clearly in (32) below by a 'minimal pair' taken from a narrative in Evenki, a close sister of Negidal and Even. As can be seen from the sequence provided here, the narrative is about going

${ }^{12}$ However, it is of course possible that there is a bias in the studies up to date, with the category being described mainly in languages that use it frequently. 
to hunt a bear (referred to by the euphemism 'bandit'). In (32a), in which the hunters take the decision to hunt and kill the bear, this is encoded as the direct object of the verb event 'hunt', as expressed by the accusative case. In (32c), in contrast, it is encoded as the Goal argument of the motion event, taking the locative-allative suffix -tula: This choice is arguably due to the shift of discourse prominence onto the motion event, as shown by the sequence of utterances referring to the motion $(32 b, d, e)$.

a. Stony Tunguska Evenki (Kazakevich et al. 2007)
čajit tar čajit-pa
taro
ayi-wa:t
bandit DIST bandit-ACC DIST.ACC
HESIT-IMP.1PL.INCL
čok-na:- $\gamma a$ :t
kill-AM-IMP.1PL.INCL
'Let's do this, let's go and kill that bear (lit. 'bandit').'

b. Stony Tunguska Evenki (Kazakevich et al. 2007)

$\begin{array}{llll}n u & b u & \text { suru-ro-w } & \text { ta:-la } \\ \text { well.R } & \text { 1PL.EXCL } & \text { go-NFUT-1PL.EXCL } & \text { DIST-LOC }\end{array}$

'Well, we went there.'

c. Stony Tunguska Evenki (Kazakevich et al. 2007)

čok-na:-s-tə-w čayit-tula:

kill-AM-INCEP-NFUT-1PL.EXCL bandit-LOC

'We went to the bear to kill.'

d. Stony Tunguska Evenki (Kazakevich et al. 2007)

oro-r-di suru-ro-w

reindeer-PL-INS go-NFUT-1PL.EXCL

'We went by reindeer.'

e. Stony Tunguska Evenki (Kazakevich et al. 2007)

ama-ro- $w$

come-NFUT-1PL.EXCL

'We arrived.'

Nevertheless, although examples such as (32a-e) clearly show that the discourse prominence of the motion event vs. the verb event plays a role in the choice of argument structure, this cannot be the only factor. This is shown by examples such as $(21 \mathrm{~b})$ : here the presence of the noun phrase 'by motorbike', which is licensed by the motion event, indicates that the motion event is quite prominent, yet it is not the Goal of the motion event that is coded, but the direct object of the verb event. It is thus likely that the choice of argument structure in AM-constructions in the Tungusic languages depends on a complex interplay of formal preferences with respect to the number of overt arguments to be expressed and pragmatic needs of foregrounding specific events.

In this context it is possible that the vagueness between prior motion and motioncum-purpose readings of the $n d A$-verbs described in Section 3.2 plays a role in their mixed argument structure. In motion-cum-purpose readings the motion event can be considered more central than the verb event (as shown by the fact that the motion event can be completed while the verb event has not yet begun), and this might facilitate overt expression of spatial arguments. Whether overt spatial arguments occur more frequently in constructions with motion-cum-purpose readings than in those with clear sequential readings needs further investigation. However, it should be noted that constructions with a clear motion-cum-purpose reading in which it is the verb argument, and not the spatial 
argument, that is expressed, are also cross-linguistically attested; cf. Aissen (1994) for Tzotzil and Zavala Maldonado (2000: 142-144) for Olutec.

In summary, the Tungusic languages investigated here show flexibility of argument encoding in AM-constructions. From the extant literature this kind of flexibility and the possibility of overtly expressing the spatial argument appear to be crosslinguistically rare. However, more typological studies of AM-constructions that explicitly address argument encoding strategies are needed before this claim can be considered conclusive.

\section{Abbreviations}

1, 2, 3 - 1, 2, 3 person; ABL — ablative; ACC - accusative; ADV — adverbial; ALL - allative; ALN - alienable; AM — associated motion; ANT — anterior; ASSERT — assertive; CAUS — causative; COM - comitative; CONAT - conative; COND - conditional; COORD - coordinative; CVB - converb; DAT — dative; DECES — decessive; DEST — destinative; DIM — diminutive; DIST — distal demonstrative; DISTR - distributive; DP — discourse particle; DUR - durative; ELAT — elative; EMPH — emphatic; EXCL - exclusive; EXPR - expressive; FOC — focus; FUT — future; GNR - generic; HAB — habitual; HESIT — hesitative; IMP — imperative; IPFV — imperfective; INCEP — inceptive; INCL — inclusive; INS — instrumental; LOC - locative; MULT - multiplicative; NEG - negative; NFUT — non-future; NMLZ nominalizer; OBL — oblique; ORD — ordinal; PL — plural; POSS — possessive; POT — potential; PREFL — possessive reflexive; PRES — presumptive; PROG - progressive; PROL — prolative; PROX — proximal demonstrative; PRS — present; PST — past; PTCP — participle; PTL — particle; PURP — purposive; Q — question particle; QUOT — quotative; R — Russian copy; RECP — reciprocal; REP — repeated action; RES — resultative; RSTR — restrictive; SBJV — subjunctive; SG — singular; SIDE — side (nominal derivation); SIM — simultaneous; TAM1 — tense-aspect-modality 1; VBLZ — verbalizer; Y — Yakut copy.

\section{Acknowledgements}

Brigitte Pakendorf thanks the Volkswagen Foundation, the Max Planck Society, the CNRS, and the Endangered Languages Documentation Programme (ELDP, www.eldp.net) for funding the field trips to collect the Even and Negidal data, and also acknowledges the LABEX ASLAN (ANR-10-LABX-0081) of Université de Lyon for its financial support within the program "Investissements d'Avenir" (ANR-11-IDEX-0007) of the French government operated by the National Research Agency (ANR). Furthermore, we thank our colleagues from Dynamique du Langage for helpful discussion of our data during a seminar, Antoine Guillaume, Harold Koch, Guillaume Jacques, and Jean-Christophe Verstraete for feedback on our manuscript, and Yuriy Koryakov for providing the map in Figure 2. For help with transcriptions, translations and clarification of the narrative data we thank: Ekaterina Shadrina, Ija Krivoshapkina, and Rimma Egorova (Even), Daria Nadeina, Galina Kandakova, and Antonina Kazarova (Negidal), Raisa Bel'dy and Nikolay Bel'dy (Naikhin Nanai), and Natalia Kuchekta, Natalia Kujsali, Alla Kujsali and Nadezhda Dechuli (Ulch). We are grateful to Natalia Aralova for access to the Even narratives which she recorded and glossed and to Sofia Oskolskaya, who was the organizer of the field trips to the Nanai and who collected, transcribed and glossed the Nanai and Ulch text collections used in the study together with Natalia Stoynova. Last, but definitely not least, we thank all the speakers who contributed to the corpora and participated in the elicitation tasks.

\section{Appendix: Text collections used in this study}




\begin{tabular}{|c|c|c|c|}
\hline Language & Genres & Source & Comments \\
\hline Nanai & folklore & Avrorin 1986 & $\begin{array}{l}\text { Middle Amur (Naikhin) Nanai texts } \\
\text { (№ 13-24) }\end{array}$ \\
\hline Nanai & folklore & $\begin{array}{l}\text { Bel'dy, Bulgakova } \\
2012\end{array}$ & $\begin{array}{l}\text { Middle Amur Nanai texts (all except } \\
\text { № 4, № 22) }\end{array}$ \\
\hline Nanai & $\begin{array}{l}\text { folklore, biographic } \\
\text { texts, ethnographic } \\
\text { descriptions }\end{array}$ & $\begin{array}{l}\text { unpublished } \\
\text { collection of S. } \\
\text { Oskolskaya and } \mathrm{N} . \\
\text { Stoynova }\end{array}$ & $\begin{array}{l}\text { The texts were collected by S. } \\
\text { Oskolskaya, N. Stoynova and K. } \\
\text { Shagal in Khabarovsk Kray between } \\
\text { 2008-2017 (only Middle Amur Nanai } \\
\text { texts were used in the study). }\end{array}$ \\
\hline Ulch & $\begin{array}{l}\text { folklore, biographic } \\
\text { texts, ethnographic } \\
\text { descriptions }\end{array}$ & $\begin{array}{l}\text { unpublished } \\
\text { collection of S. } \\
\text { Oskolskaya and } \mathrm{N} \text {. } \\
\text { Stoynova }\end{array}$ & $\begin{array}{l}\text { The texts were collected in 2017-2018 } \\
\text { by NS and S. Oskolskaya in Bulava and } \\
\text { Bogorodskoje (Ulchsky district). }\end{array}$ \\
\hline Ulch & $\begin{array}{l}\text { folklore, biographic } \\
\text { texts }\end{array}$ & $\begin{array}{l}\text { unpublished } \\
\text { collection of L.I. } \\
\text { Sem }\end{array}$ & $\begin{array}{l}\text { The texts were recorded in } 1971 \text { and } \\
1979 \text { by L. I. Sem and Yu. A. Sem in } \\
\text { Bulava (Ulchsky district), digitalized } \\
\text { by S. Oskolskaya and transcribed by } \\
\text { NS. }\end{array}$ \\
\hline Udihe & folklore & $\begin{array}{l}\text { Nikolaeva et al. } \\
2003\end{array}$ & Texts № 1-15 \\
\hline Udihe & folklore & $\begin{array}{l}\text { Nikolaeva et al. } \\
2002\end{array}$ & \\
\hline $\begin{array}{l}\text { Lamunkhin } \\
\text { Even }\end{array}$ & $\begin{array}{l}\text { biographical and } \\
\text { historical narratives, } \\
\text { folklore, procedural } \\
\text { text, conversation }\end{array}$ & $\begin{array}{l}\text { Pakendorf corpus } \\
\text { (partly available at: } \\
\text { http://dobes.mpi.nl/ } \\
\text { projects/even/) }\end{array}$ & $\begin{array}{l}\text { The corpus was collected by BP in } \\
\text { Sebjan-Küöl between 2008-2012, with } \\
\text { assistance by N. Aralova in 2010. }\end{array}$ \\
\hline $\begin{array}{l}\text { Bystraja } \\
\text { Even }\end{array}$ & $\begin{array}{l}\text { biographical and } \\
\text { historical narratives, } \\
\text { folklore, procedural } \\
\text { text, conversation }\end{array}$ & $\begin{array}{l}\text { Pakendorf corpus } \\
\text { (partly available at: } \\
\text { http://dobes.mpi.nl/ } \\
\text { projects/even/) }\end{array}$ & $\begin{array}{l}\text { The corpus was collected by BP in } \\
\text { Kamchatka between 2007-2016, with } \\
\text { assistance by N. Aralova in 2009; some } \\
\text { of the audio recordings were done by } \\
\text { A. Lavrillier in 2010. }\end{array}$ \\
\hline Negidal & $\begin{array}{l}\text { biographical and } \\
\text { historical narratives, } \\
\text { folklore, procedural } \\
\text { text, conversation }\end{array}$ & $\begin{array}{l}\text { Pakendorf and } \\
\text { Aralova } 2017 \\
\text { (https://elar.soas.ac. } \\
\text { uk/Collection/MPI1 } \\
\text { 041287) }\end{array}$ & \\
\hline
\end{tabular}

\section{References}

Aissen, Judith L. 1994. Tzotzil auxiliaries. Linguistics 32 (4-5). 657-690.

Alonso de la Fuente, José Andrés \& Guillaume Jacques. 2018. Associated motion in Manchu in typological perspective. Language and Linguistics 19 (4). 501-524. 
Atknine, Victor. 1997. The Evenki Language from the Yenisei to Sakhalin. In Hiroshi Shoji \& Juha Janhunen (eds.), Northern Minority Languages. Problems of Survival. Papers Presented at the Eighteenth Taniguchi International Symposium: Division of Ethnology, 109-121. Osaka: National Museum of Ethnology.

Avrorin, Valentin A. 1959. Grammatika nanajskogo jazyka. Tom pervyj [A grammar of Nanai. vol. 1]. Moscow, Leningrad: Izdatel'stvo Akademii Nauk SSSR.

Avrorin, Valentin A. 1961. Grammatika nanajskogo jazyka. Tom vtoroj [A grammar of Nanai. vol. 2]. Moscow, Leningrad: Izdatel'stvo Akademii Nauk SSSR.

Avrorin, Valentin A. 1981. Sintaksičeskije issledovanija po nanajskomu jazyku [Studies of Nanai syntax]. Leningrad: 'Nauka.'

Avrorin, Valentin A. 1986. Materialy po nanajskomu jazyku i fol'kloru [Materials on the Nanai language and folklore]. Leningrad: Nauka.

Avrorin, Valentin A. 2000. Grammatika man'čžurskogo pis'mennogo jazyka [A grammar of written Manchu]. Saint Petersburg: Nauka.

Bel'dy, Raisa A. \& Tatiana D. Bulgakova. 2012. Nanajskie skazki [Nanai fairy tales] (Languages and Cultures of the Russian Far East). Fürstenberg: Verlag der Kulturstiftung Sibirien / SEC Publications.

Benzing, Johannes. 1955. Die tungusischen Sprachen. Versuch einer vergleichenden Grammatik (Akademie der Wissenschaften und Der Literatur. Abhandlungen der Geistes- Und Sozialwissenschaftlichen Klasse). Vol. 11. Wiesbaden: Verlag der Akademie der Wissenschaften und der Literatur in Mainz in Kommission bei Franz Steiner Verlag.

Burykin, Aleksej A. 2004. Jazyk maločislennogo naroda v ego pis'mennoj forme. Sociolingvističeskie i sobstvenno lingvističeskie aspekty [The language of a minority people in its written form. Sociolinguistic and linguistic aspects]. St Petersburg: Peterburgskoe Vostokovedenie.

Census

2010.

http://www.gks.ru/free doc/new_site/perepis2010/croc/Documents/Vol4/pub-0420.pdf. (Accessed on 01.09.2018).

Cincius, Vera I. 1982. Negidal'skij jazyk. Issledovanija i materialy [Negidal. Analysis and materials]. Leningrad: Nauka.

Comrie, Bernard. 1981. The Languages of the Soviet Union. Cambridge: Cambridge University Press.

Dryer, Matthew S. This volume, chapter 13. Associated Motion in North America.

Gerasimova, Anna N. 2002. Nanajskij i ul'čskij jazyki v Rossii: sravnitel'naja xarakteristika sociolingvističeskoj situacii [Nanai and Ulch in Russia: comparative characteristics of the sociolinguistic situation]. Jazyki korennyx narodov Sibiri 12. 246-257.

Guillaume, Antoine. 2006. La catégorie du "mouvement associé" en cavineña: Apport à une typologie de l'encodage du mouvement et de la trajectoire. Bulletin de la Société de Linguistique de Paris 101 (1). 415-436.

Guillaume, Antoine. 2016. Associated motion in South America: Typological and areal perspectives. Linguistic Typology 20 (1). 81-177.

Haviland, John B. 1993. The syntax of Tzotzil auxiliaries and directionals: the grammaticalization of motion. Berkeley Linguistics Society 19 (2). 35-49.

Jacques, Guillaume, Aimée Lahaussois, and Shuya Zhang. This volume, chapter 21. Associated motion in Sino-Tibetan, with a focus on Gyalrongic and Kiranti.

Janhunen, Juha. 2012. The expansion of Tungusic as an ethnic and linguistic process. In Andrei L. Malchukov \& Lindsay J. Whaley (eds.), Recent Advances in Tungusic Linguistics (Turcologica 89), 5-16. Wiesbaden: Harrassowitz. 
Kalinina, Elena Ju \& Sofia A. Oskolskaya. 2016. Nanajskij jazyk. [Nanai]. In Vida Ju. Mixal'čenko (ed.), Jazyk i obščestvo. Enciklopedija [Language and Society. An Encyclopaedia], 293-296. Moscow: Azbukovnik.

Kazakevich, Ol'ga A., Evgenija A. Renkovskaja, Darija Vaxoneva and Nadežda Mamontova. 2007. Èkspedicija k èvenkam Podkamennoj Tunguski [Expedition to the Evenks of the Stony Tunguska]. Na Severnoj Tajmure [On the Northern Tajmur], told by S.M. Andreeva. http://siberian-lang.srcc.msu.ru/ru/text/na-severnoytaymure-s-m-andreeva. (Accessed on 29.01.2018).

Khasanova, Marina M. \& Alesandr M. Pevnov. 2003. Mify i skazki negidal'cev [Myths and tales of the Negidals.] (Endangered Languages of the Pacific Rim A2-024). Kyoto: Nakanishi.

Koch, Harold. 1984. The category of 'associated motion' in Kaytej. Language in central Australia 1 (1). 23-34.

Koch, Harold. This volume, chapter 7. Associated Motion in the Pama-Nyungan languages of Australia.

Kolesnikova, Vera D. \& Ol'ga A. Konstantinova. 1968. Negidal'skij jazyk [Negidal]. In Pëtr Ja. Skorik, Valentin A. Avrorin, Trofim A. Bertagaev, Georgij A. Menovščikov, Orest P. Sunik \& Ol'ga A. Konstantinova (eds.), Mongol'skie, tunguso-man 'čžurskie i paleoaziatskie jazyki. [Mongolian, Tungusic, and Paleoasiatic languages] (Jazyki Narodov SSSR [Languages of the Peoples of the USSR.] 5), 109-128. Leningrad: Nauka, Leningradskoe otdelenie.

Levinson, Stephen C. \& David P. Wilkins. 2006. Patterns in the data: Toward a semantic typology of spatial description. In Stephen C. Levinson \& David P. Wilkins (eds.), Grammars of Space: Explorations in Cognitive Diversity, 512-552. Cambridge: Cambridge University Press.

Malchukov, Andrey L. 1995. Even. München, Newcastle: LINCOM Europa.

Mithun, Marianne. 2002. Understanding and explaining applicatives. In Mary Andronis, Christopher Ball, Heidi Elston \& Sylvain Neuvel (eds.), Proceedings of the Thirtyseventh Meeting of the Chicago Linguistic Society: Functionalism and formalism in linguistic theory, 37 (2), 73-98. Chicago.

Nikolaeva, Irina, Elena Perekhvalskaya \& Maria Tolskaya. 2002. Udeghe (Udihe) Folk Tales (Tunguso-Sibirica). Vol. 10. Wiesbaden: Harrassowitz Verlag.

Nikolaeva, Irina, Elena Perekhvalskaya \& Maria Tolskaya. 2003. Udeghe Texts (Endangered Languages of the Pacific Rim). Vol. A2-025. Kyoto: ELPR.

Nikolaeva, Irina \& Maria Tolskaya. 2001. A grammar of Udihe. Berlin, New York: Mouton de Gruyter.

Novikova, Klavdija A. 1980. Očerki dialektov èvenskogo jazyka. Glagol, služebnye slova, teksty, glossarij. [Sketches of Even dialects. Verb, auxiliary words, texts, glossary]. Leningrad: Nauka.

O'Connor, Loretta. 2004. Going getting tired: Associated motion through space and time in Lowland Chontal. In Michel Achard \& Suzanne Kemmer (eds.), Language, culture and mind, 181-199. Stanford: Centre for the Study of Language and Information.

O'Connor, Loretta. 2007. Motion, transfer and transformation: The grammar of change in lowland Chontal. Amsterdam, Philadelphia: John Benjamins.

Pakendorf, Brigitte \& Natalia Aralova. 2017. Documentation of Negidal, a nearly extinct Northern Tungusic language of the Lower Amur. London: SOAS, Endangered Languages Archive. https://elar.soas.ac.uk/Collection/MPI1041287.

Pakendorf, Brigitte \& Natalia Aralova. 2018. The endangered state of Negidal: A field report. Language Documentation and Conservation. http://scholarspace.manoa.hawaii.edu/handle/10125/24760. 
Pakendorf, Brigitte \& Raisa P. Kuz'mina. 2016. Èvenskij jazyk [Even]. In Vida Ju. Mixal'čenko (ed.), Jazyk i obščestvo. Énciklopedija [Language and Society. An Encyclopaedia], 583-587. Moscow: Azbukovnik.

Payne, Doris L. This volume, chapter 18. The extension of Associated Motion to Direction, Aspect and Argument Structure in Nilotic languages.

Petrova, Taisija I. 1936. Ul'čskij dialect nanajskogo jazyka [The Ulch dialect of Nanai]. Moscow, Leningrad: Učpedgiz.

Rose, Françoise. 2015. Associated motion in Mojeño Trinitario: Some typological considerations. Folia Linguistica 49 (1). 117-158.

Ross, Daniel. This volume, chapter 2. A cross-linguistic survey of Associated Motion and Directionals.

Simpson, Jane. 2001. Preferred word order and the grammaticalization of Associated Path. In Miriam Butt \& Tracy Holloway King (eds.), Time over matter: diachronic perspectives on morphosyntax, 173-208. Stanford: Centre for the Study of Language and Information.

Stoynova, Natal'ja M. 2016. Pokazateli “dviženija s cel'ju” i sobytijnaja struktura: suffiks -nda v nanajskom jazyke [Markers of "motion-cum-purpose" and event structure: $n d a$ suffix in Nanai]. Voprosy Jazykoznanija 4. 86-111.

Stoynova, Natal'ja M. 2017. Pokazateli dviženija s cel'ju v južnotungusskix jazykax i kategorija associated motion [Motion-cum-purpose markers in the Southern Tungusic languages and the typology of associated motion]. Problemy jazyka. Sbornik naučnyx statej po materialam Pjatej konferencii-školy "Problemy jazyka: vzgljad molodyx učenyx" [Problems of Language: Collection of Scientific Papers from the Materials of the Third Conference-School "Problems of Language: A View of Young Scholars"], 321-339. Moscow: Institut jazykoznanija RAN, Izdatel'stvo "Kancler."

Sumbatova, Nina R. \& Valentin Ju. Gusev. 2016. Ul'čskij jazyk [Ulch]. In Vida Ju. Mixal'čenko (ed.), Jazyk i obščestvo. Ėnciklopedija [Language and Society. An Encyclopaedia], 513-515. Moscow: Azbukovnik.

Sunik, Orest P. 1968. Tunguso-man'čžurskie jazyki (vvedenie) [Tungus-Manchu languages (introduction)]. In Pëtr Ja. Skorik, Valentin A. Avrorin, Trofim A. Bertagaev, Georgij A. Menovščikov, Orest P. Sunik \& Ol'ga A. Konstantinova (eds.), Jazyki narodov SSSR: Mongol'skie, tunguso-man'čžurskie i paleoaziatskie jazyki [Languages of the peoples of the USSR: Mongolic, Tungusic and Paleoasiatic languages], 53-67. Leningrad: Izdatel'stvo ,Nauka' Lenigradskoe otdelenie.

Sunik, Orest P. 1985. Ul'čskij jazyk. Issledovanija $i$ materialy [Ulča. Study and materials]. Leningrad: Nauka.

Tallman Adam J.R. This volume, chapter 11. Associated motion in Chácobo (Pano) in typological perspective.

Volkov, Oleg S. \& Ivan A. Stenin. 2019. Andativ i ventiv v jazykax Sibiri: k tipologii glagol'noj orientacii [Andative and ventive in the languages of Siberia: towards a typology of verb orientation]. Acta Linguistica Petropolitana 15 (1) [Special issue for A.P. Volodin's 80th birthday]. 289-319.

Wilkins, David P. 1991. The semantics, pragmatics and diachronic development of "associated motion" in Mparntwe Arrernte. Buffalo Papers in Linguistics 1. 207257.

Zavala Maldonado, Roberto. 2000. Olutec motion verbs: Grammaticalization under Mayan contact. Berkeley Linguistics Society 26 (2). 139-151. 